HUMBERTO GABRIEL RODRIGUES

ESTUDO DA PREVALÊNCIA DE DEFEITOS DE TUBO NEURAL NO BRASIL E DO PADRÃO DE CONSUMO DE ÁCIDO FÓLICO EM GESTANTES DO VALE DO JEQUITINHONHA, BRASIL

BRASÍLIA 
HUMBERTO GABRIEL RODRIGUES

ESTUDO DA PREVALÊNCIA DE DEFEITOS DE TUBO NEURAL NO BRASIL E DO PADRÃO DE CONSUMO DE ÁCIDO FÓLICO EM GESTANTES DO VALE DO JEQUITINHONHA, BRASIL

Tese apresentada como requisito parcial para a obtenção do Título de Doutor em Ciências da Saúde pelo Programa de Pós-Graduação em Ciências da Saúde da Universidade de Brasília.

Orientadora: Prof. Dra . Leonor Maria Pacheco Santos Co-orientadora: Prof. Drª. Muriel Baeurmann Gubert

BRASÍLIA 


\title{
ESTUDO DA PREVALÊNCIA DE DEFEITOS DE TUBO NEURAL NO BRASIL E DO PADRÃO DE CONSUMO DE ÁCIDO FÓLICO EM GESTANTES DO VALE DO JEQUITINHONHA, BRASIL
}

\begin{abstract}
Tese apresentada como requisito parcial para a obtenção do Título de Doutor em Ciências da Saúde pelo Programa de Pós-Graduação em Ciências da Saúde da Universidade de Brasília.
\end{abstract}

Aprovado em 04 de dezembro de 2014

Orientadora: Prof. Drª Leonor Maria Pacheco Santos

Departamento de Saúde Coletiva

Universidade de Brasília

Prof. Dra . Marina Kiyomi Ito

Departamento de Ciências da Saúde

Universidade de Brasília

Prof. Drª. Daphne Rattner

Departamento de Saúde Coletiva

Universidade de Brasília

Prof. Dr. Antônio Prates Caldeira

Departamento de Saúde da Mulher e da Criança

Universidade Estadual de Montes Claros

Dra . Gisele Ane Bortolini

Coordenação Geral de Alimentação e Nutrição

Ministério da Saúde

Suplente: Prof. Dr ${ }^{\mathrm{a}}$ Maria Paula do Amaral Zaitune

Departamento de Saúde Coletiva

Universidade de Brasília 
Dedico este trabalho à minha família, por todo o apoio $\mathrm{e}$ incentivo em mim depositados, e a todas as gestantes do Brasil, especialmente as do Vale do Jequitinhonha, que muito me ensinaram. 


\title{
AGRADECIMENTOS
}

\begin{abstract}
À Professora Leonor Pacheco, por ter acreditado, confiado em mim e pela enorme esforço, dedicação e profissionalismo demonstrados durante a orientação.
\end{abstract}

À professora Muriel Gubert, por ter-me co-orientado, pela paciência e pela ajuda oportuna.

Ao Roberto Lecca e Juan Escalante, pela colaboração na coleta de dados junto ao Ministério da Saúde.

Ao professor Mauro Sanchez, pela ajuda oportuna e enriquecedora.

À melhor equipe de trabalho de campo que eu poderia ter, Karide Ladeia, Jéssica Dayane, Israelita David, Ertz Ramon, Fábio Alexandre, Luciane Vanelle, Jéssica Carvalho, Jéssica Benevides, Adailson Amorim, Ronilson Freitas, Fábio Gutemberg, Uélcio Cangussu, Isabella de Cássia, Priscila Franciane e Maristela Itabaiana.

Aos professores Ernani Mendes e Jackson Andrade, pelo apoio em estatística,

À todas as gestantes do Vale do Jequitinhonha que participaram da pesquisa, pelos valiosos ensinamentos.

À professora Lucinéia de Pinho, pela parceria e consultoria nutricional.

Aos Secretários de Saúde de cada município pesquisado, pela atenção e colaboração. 
Às Faculdades Integradas Pitágoras de Montes Claros e às Faculdades Santo Agostinho, pela compreensão, apoio e incentivo.

A meus amigos, por sempre terem uma palavra de incentivo.

A todos aqueles que, direta ou indiretamente, contribuíram para a realização deste trabalho. 
"Haverá mãe que possa esquecer seu bebê que ainda mama e não ter compaixão do filho que gerou? Embora ela possa esquecê-lo, eu não me esquecerei de você!"

Isaías 49:15 


\section{RESUMO}

O ácido fólico é um micronutriente imprescindível ao metabolismo normal do organismo, e sua deficiência pode acarretar prejuízos irreversíveis à saúde das gestantes e, principalmente, de seus filhos como os Defeitos do Tubo Neural (DTNs). Em junho de 2004, no Brasil, o Ministério da Saúde determinou a fortificação obrigatória das farinhas de trigo e milho com ácido fólico, para prevenir a ocorrência desses defeitos congênitos. Dessa forma, para testar a hipótese de que a fortificação obrigatória de farinhas com ácido fólico contribuíram para evitar a ocorrência de defeitos no tubo neural, este trabalho apresenta dois importantes objetivos. O primeiro é o de estimar a prevalência desses defeitos, no Brasil, antes e depois da política de fortificação obrigatória, mediante o estudo transversal retrospectivo populacional baseado em dados secundários dos Sistemas de Informações sobre Mortalidade e de Nascidos Vivos, em oito estados brasileiros com alta cobertura de notificação nos períodos pré (2001-2004) e pós-fortificação (20052010). O segundo objetivo tem a finalidade de determinar o padrão de consumo de folato por gestantes no Vale do Jequitinhonha, Minas Gerais, Brasil, uma das regiões mais pobres do país e, dessa forma, também verificar a efetividade da política de fortificação obrigatória das farinhas de trigo e milho com ácido fólico. Para a pesquisa nacional de DTNs, foram analisados 12.556 .701 registros de nascidos vivos e 142.915 registros de óbitos fetais identificados pelos códigos Q00 (anencefalia), Q01 (encefalocele) e Q05 (espinha bífida) da Classificação Internacional de Doenças, 10 ${ }^{\underline{a}}$ versão (CID-10). Para a pesquisa regional de dados primários sobre o consumo de ácido fólico entre gestantes, foi realizada uma pesquisa descritiva do tipo transversal, com 492 gestantes atendidas em Unidades Básicas de Saúde do Sistema Único de Saúde (SUS), em 15 municípios do Vale do Jequitinhonha, no ano de 2013, por meio de um questionário padronizado, que incluía dados sócio-econômicos e inquérito de frequência alimentar. Os resultados de ambas as pesquisas foram analisados e comparados estatisticamente, com base em razões de prevalência, com intervalo de confiança de 95\%, e mostraram efetividade da política de fortificação obrigatória. A análise nacional de DTNS mostrou que a prevalência média foi de 0,79:1000 nascimentos para o período 2001 - 
2004, e 0,54: 1000 nascimentos no período 2005-2010 (razão de prevalência 1,47, $\left.\mathrm{IC}_{95 \%}[1,41-1,53]\right)$, mostrando um declínio de $31,6 \%$ no número de casos de DTNs após a fortificação obrigatória. As reduções atingiram $34.1 \%$ nos casos de anencefalia e 31,0\% nos casos de espinha bífida. A análise regional do consumo alimentar realizada no Vale do Jequitinhonha mostrou que a prevalência de consumo insuficiente de folato foi de $94,7 \%$, desconsiderando a inclusão de alimentos fortificados; de $49,2 \%$ considerando a dieta com alimentos fortificado (redução de 45,5\%) e de $17,1 \%$ considerando folato alimentar, alimentos enriquecidos, e suplementação com ácido fólico. Dessa forma, tanto os resultados de prevalência de DTNs como os de consumo alimentar indicam a efetividade da política de fortificação obrigatória de farinhas de trigo e milho com ácido fólico.

PALAVRAS-CHAVE: ácido fólico; defeitos do tubo neural; prevalência; Brasil. 


\section{ABSTRACT}

Folic acid is a micronutrient that is essential for the normal metabolism of the organism and its deficiency can result in often irreversible health effects to pregnant women and especially for of their children, such as Neural Tube Defects (NTDs). In June 2004, in Brazil, the Ministry of Health established the mandatory fortification of flour with folic acid to prevent these birth defects. Thus, to test the hypothesis that mandatory fortification of flour with folic acid helped to prevent the occurrence of neural tube defects, this work presents two important objectives. The first is to estimate the prevalence of these defects in Brazil before and after mandatory fortification through a population-based retrospective cross-sectional study based on secondary data from the Mortality Information System and Live Births in eight states with high coverage notification in periods before (2001-2004) and after fortification (2005-2010). The second objective is to determine the pattern of consumption of folate by pregnant women in Vale do Jequitinhonha, Minas Gerais state, Brazil, one of the poorest regions of the country and thus also to verity the effectiveness of the mandatory fortification of wheat and corn flour with folic acid policy. For the national survey of NTDs a total of 12,556,701 records of live births and fetal deaths of 142,915 records identified by Q00 (anencephaly), Q01 (encephalocele) and Q05 (spina bifida) International Classification of Diseases codes, 10th version were analyzed. For the regional survey of primary data on the consumption of folic acid among pregnant womem a descriptive cross-sectional study was held with 492 pregnant women assisted in Basic Health Units run by Public Health Service (Sistema Único de Saúde, SUS) in 15 municipalities of Vale do Jequitinhonha in 2013 through a standardized questionnaire, which included socioeconomic indicators and a food frequency questionnaire. The results of both surveys were analyzed and compared statistically based on prevalence ratios with confidence intervals of $95 \%$ and showed effectiveness of the policy of mandatory fortification. National NTDs analysis showed that the average incidence was 0.79: 1000 births for the period of 2001-2004 and 0.54: 1000 births in 2005-2010 (prevalence ratio 1.47, Cl 95\%[1.411.53]), showing a $36.1 \%$ decline in the number of cases of NTDs after mandatory 
fortification. Reductions achieved $34.1 \%$ for anencephaly and $31.0 \%$ for spina bifida by $31.0 \%$. The regional analysis of food consumption carried out in Vale do Jequitinhonha showed that the prevalence of inadequate folate intake in the diet was $94.7 \%$, excluding the contribution of fortified foods; $49.2 \%$ for the diet with fortified foods, (reduction of $45.5 \%$ ) and $17.1 \%$ based on food folate, fortified foods, and folic acid supplementation. Thus the results of prevalence of NTDs, as well as of food consumption, indicate the effectiveness of the mandatory fortification of wheat and corn flour with folic acid policy.

KEYWORDS: folic acid; neural tube defects; prevalence; Brazil. 


\section{LISTA DE ABREVIATURAS E SIGLAS}

ANVISA - Agência Nacional de Vigilância Sanitária

CDC - Centers for Disease Control and Prevention

CID 10 - Código Internacional de Doenças $10^{\underline{a}}$ revisão

DEF - Equivalente de Folato Dietético

DTN - Defeitos do Tubo Neural

ECLAMC - Estudo Colaborativo Latino-Americano de Malformações Congênitas

IBGE - Instituto Brasileiro de Geografia e Estatística

IC $95 \%$ - Intervalo de Confianças de 95\%.

MTHFR - Metilenotetra-Hidrofolato Redutase

QFA - Questionário de Frequência Alimentar

RDA - Recommended Dietary Allowances

RDC - Resolução da Diretoria Colegiada

RN - Recém-Nascido

RP - Razão de Prevalências

SINASC - Sistema de Informações sobre Nascidos Vivos

SIM - Sistema de Informações sobre Mortalidade

TCA - Tabela de Composição de Alimentos

UBS - Unidade Básica de Saúde

UL - Tolerable Upper Intake Levels 


\section{SUMÁRIO}

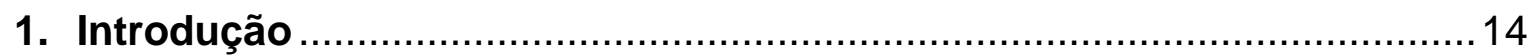

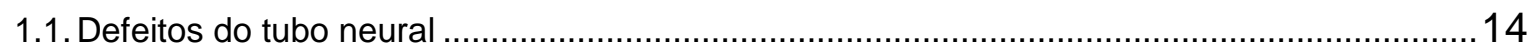

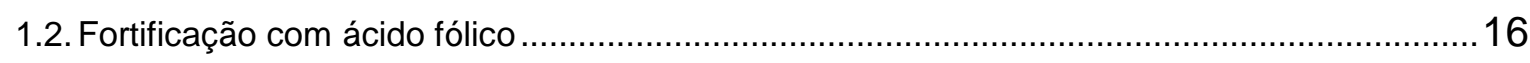

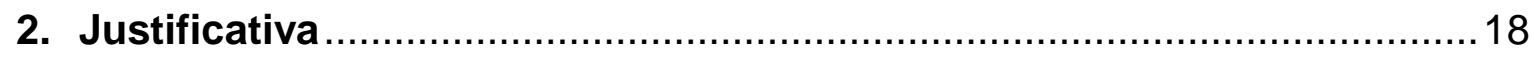

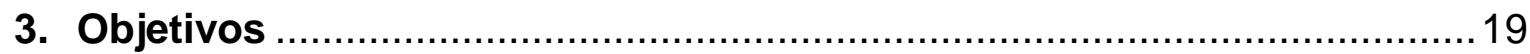

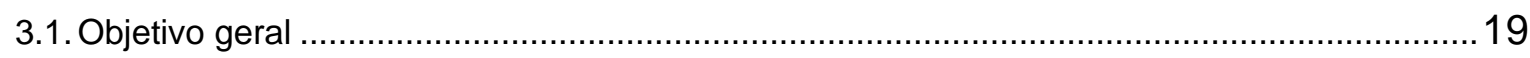

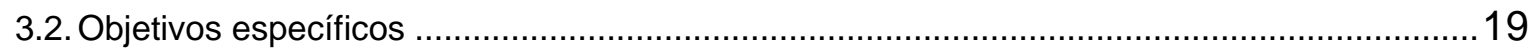

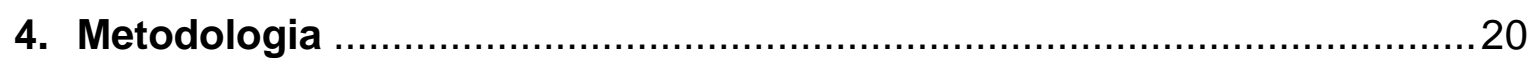

4.1. Metodologia do estudo nacional com dados secundários: Efetividade da fortificação obrigatória na prevenção de defeitos do tubo neural no Brasil.............................................20

4.2. Metodologia do estudo regional com dados primários: Consumo de ácido fólico por gestantes do Vale do Jequitinhonha, Brasil, e a contribuição dos alimentos fortificados

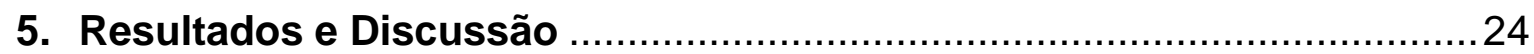

5.1. Artigo 1: Effectiveness of mandatory folic acid fortification in the prevention of neural tube defects in Brazil

5.2. Artigo 2: Folic acid intake by pregnant women from Vale do Jequitinhonha, Brazil, and the contribution of fortified foods

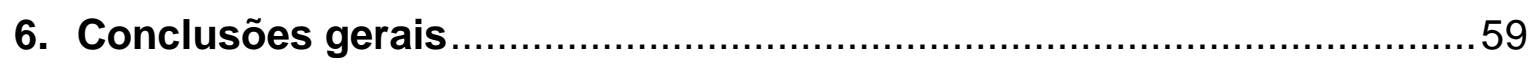

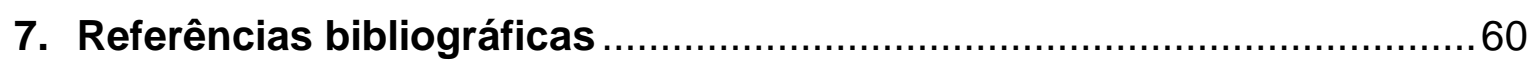

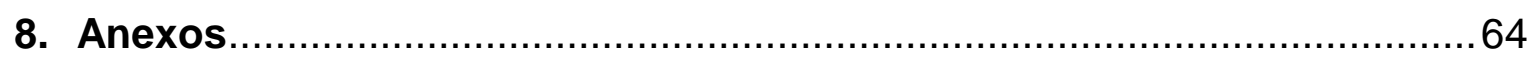

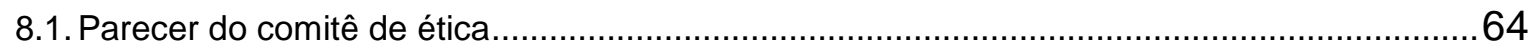

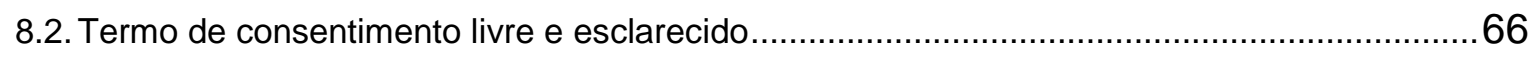

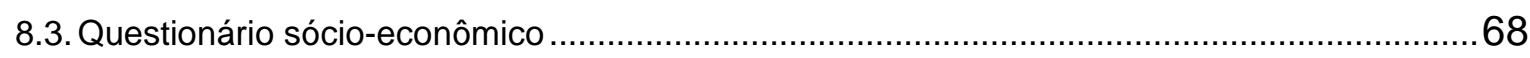

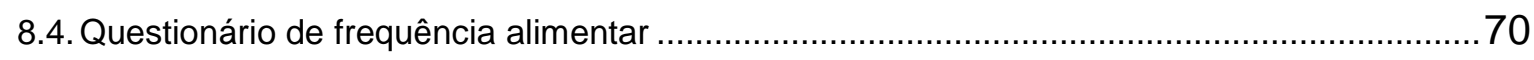

8.5. Conversão de medidas caseiras do questionário de frequência alimentar .............................74

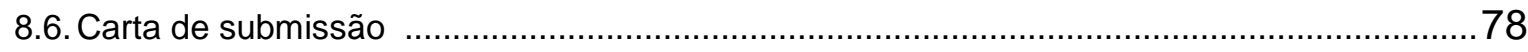

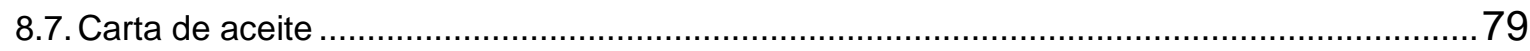




\section{INTRODUÇÃO}

\subsection{DEFEITOS DO TUBO NEURAL}

Os defeitos do tubo neural (DTNs) estão entre as mais importantes causas congênitas de morbidade e mortalidade infantil, ocorrendo em 300 mil recém-nascidos a cada ano em todo o mundo (1). Esses defeitos são decorrentes do fechamento anormal do tubo neural embrionário, por volta do $22^{\circ}$ ao $28^{\circ}$ dia após a concepção. Eles resultam em defeitos estruturais que ocorrem em qualquer lugar ao longo do neuroeixo e muitas vezes resultam na exposição do tecido neural. As crianças com DTN podem apresentar paraplegia, bexiga neurogênica, infecções urinárias, insuficiencia renal, hidrocefalia e cifoescoliose, apenas para citar as manifestações mais graves ou frequentes (2).

Classicamente, os DTNs são divididos em dois principais grupos: (a) os defeitos que afetam as estruturas cranianas, tais como a anencefalia e encefalocele, e (b) defeitos que afetam as estruturas da coluna vertebral (espinha bífida). As mais comuns alterações são a espinha bífida ( $50 \%$ dos casos), anencefalia ( $40 \%$ dos casos) e, dentre os $10 \%$ restantes, destaca-se a encefalocele $(3,4)$.

A anencefalia, também chamada de exencefalia ou craniorraquisquise, é definida como a ausência completa (holoanencefalia) ou parcial (meroanencefalia) do cérebro, causada por uma falha no fechamento do tubo neural cefálico $(5,6)$. Trata-se de uma má-formação que leva a óbitos fetais, natimortos ou mortes neonatais (5).

A espinha bífida é um defeito do tubo neural caracterizado por falha na fusão dos arcos vertebrais da coluna vertebral. Esse defeito pode ser recoberto por pele essencialmente normal com desenvolvimento de manchas ou pelos (espinha bífida oculta), ou associar-se com uma protrusão cística, podendo conter meninges anormais e líquido cefalorraquidiano (meningocele); ou elementos da medula espinhal e/ou nervos (mielomeningocele). Quanto à apresentação da mielomeningocele, a junção tóraco-lombar é a localização mais comumente afetada $(45 \%)$, seguida pela lombar (20\%), lombos-sacras $(20 \%)$ e sacral $(10 \%)$. Localizações mais rostrais estão envolvidas em somente $5 \%$ dos casos $(4,5)$. Outra forma clínica encontrada nos DTN(s) é a encefalocele, na qual o cérebro e as 
meninges herniam-se através de um defeito na calota craniana, principalmente na região occipital (1).

Fatores genéticos e não-genéticos são frequentemente associados às causas dos DTNs. Entre os fatores genéticos, estão mutações gênicas simples, como a síndrome de Meckel, e anormalidades cromossômicas, como a trissomia do 13 e do 18 e, principalmente, por polimorfismos de genes associados ao metabolismo do folato, como o gene associado com a Metilenotetra-Hidrofolato Redutase (MTHFR) (6). Quanto aos fatores não-genéticos, a ocorrência de DTNs tem forte relação com o baixo consumo de folato e também está associada a fatores maternos, como a idade elevada, etnia e obesidade, além do uso de drogas antiepilépticas $(5,6,7)$.

A prevalência dos DTNs é bastante variável no mundo. Esses defeitos congênitos permanecem entre os mais frequentes e mais devastadores do mundo, no entanto, variam em diferentes épocas e regiões. Eles são baixos na Finlândia (0,4:1.000 nascimentos), altos no México (3,3:1.000) e muito altos no sul do País de Gales (até 12,5:1.000) (8,9).

No Brasil, são parcas as publicações macrorregionais e nacionais sobre a prevalência de DTNs. Há publicações de alguns municípios e regiões com grandes variações numéricas. Sua prevalência é cerca de um caso em cada 1.000 nascidos vivos em estudo realizado no Vale do Paraíba, São Paulo, em 2004 (10); pode atingir 4,73 por 1.000 nascidos vivos em trabalho realizado em Minas Gerais, entre 1990 a 2000 (11); ou 5,0 casos por 1.000 nascidos vivos, como verificado em Recife, Pernambuco, entre os anos de 2000 a 2004 (12). Valores mais baixos de prevalência foram encontrados em São José dos Campos, São Paulo, no ano de 2001, com 1,2 casos por 1.000 nascidos vivos (13). Segundo investigação do Estudo Colaborativo Latino-Americano de Malformações Congênitas (ECLAMC), o Brasil apresenta prevalências mais altas de defeitos do tubo neural de: 3,13 (1999), 3,32 (2000) e 3,36 (2001) por mil nascidos vivos (14), e média de 0,81 por mil nascidos vivos no período de 2005-2007 (15).

Para determinar a frequência de DTNs em uma população, a prevalência entre os nascidos vivos é uma prática comum. No entanto, pode não refletir a real prevalência de DTN, uma vez que não são contabilizados os óbitos fetais e natimortos portadores desse defeito congênito. Creasy e Alberman (16) fizeram estudos da prevalência de DTNs em Londres e verificaram que a prevalência de 
DTN entre óbitos fetais nas gestações de 8 semanas era de 5,3:1000, enquanto, entre os nascidos vivos, caía para 2,8:1000. Um estudo similar foi feito na Irlanda do Norte, no qual se verificaram prevalências de DTNs em gestações de 8 semanas numa proporção aproximada de 10,8:1000, enquanto que, dentre os nascidos vivos, era de 7,1:1000 (17). No Brasil, não foram encontrados estudos que relatam prevalências entre os óbitos fetais ou natimortos.

\subsection{FORTIFICAÇÃO COM ÁCIDO FÓLICO}

O folato é um micronutriente imprescindível ao metabolismo normal do organismo, e sua deficiência pode acarretar prejuízos à saúde, muitas vezes irreversíveis. Entre os grupos populacionais mais sujeitos a essas deficiências estão os pré-escolares, escolares, gestantes, nutrizes e adolescentes do sexo feminino. Nesses grupos, há um aumento da velocidade de crescimento e desenvolvimento celular e, consequentemente, aumento da demanda desse nutriente (18). Em gestantes, particularmente, outro fator que contribui para deficiência de folato é a dieta inadequada (19).

Durante a gravidez, o folato interfere no aumento das hemácias, no alargamento do útero, nos crescimentos da placenta e do feto, e na prevenção de prematuridade (20). A deficiência de folato pode estar associada a complicações da gestação como síndromes hipertensivas, hemorragias e abortos espontâneos e doenças cárdio-vasculares (21).

Porém, a deficiência de folato é descrita primordialmente como o mais importante fator de risco para os Defeitos do Tubo Neural $(1,3)$. O ácido fólico previne DTNs, pois essa vitamina é fonte de carbono para a síntese de nucleotídeos e uma variedade de reações de metilação. Sua diminuição no organismo está associada ao acúmulo de homocisteína, que, por sua vez, produz uma alteração enzimática na MTHFR, responsável pelos DTNs $(7,22,23)$.

Devido à gravidade dos Defeitos do Tubo Neural e sua morbimortalidade, torna-se muito importante garantir a adequação do consumo de ácido fólico, por meio de melhorias na dieta, pela fortificação e/ou suplementação com essa vitamina. Estudos demonstram que as contribuições suplementares de ácido fólico no período 
periconcepcional reduzem entre 60 e $70 \%$ o risco de ocorrência e recorrência de DTN $(23,24)$.

Desde 1992, tem sido preconizado o consumo de ácido fólico gestacional (25, 26). Em 1992, o Center for Diseases Control and Prevention (CDC) (25) recomendou que as mulheres que planejassem engravidar e com história familiar negativa de DTNs consumissem $40 \mathrm{mcg} / \mathrm{dia}$, mas para aquelas com alto risco (história prévia de filhos com DTNs), recomendou-se o consumo de $400 \mathrm{mcg} / \mathrm{dia}$ (25). Em 2000, o Institute of Medicine elevou essa dosagem para $600 \mathrm{mcg} / \mathrm{dia}$ (26). No Brasil, a Agência Nacional de Vigilância Sanitária (ANVISA) (27) publicou regulamento técnico sobre a ingestão diária recomendada de proteína, vitaminas e minerais em 2005, que, no caso do ácido fólico, é equivalente ao proposto pelo Institute of Medicine em 2000.

A recomendação de consumo de $600 \mathrm{mcg} / \mathrm{dia}$ do Institute of Medicine é difícil de ser alcançada por uma dieta sem alimentos fortificados, que fornece aproximadamente $250 \mathrm{mcg} / \mathrm{dia}$, considerando o valor energético total de $2200 \mathrm{Kcal}$ diárias (19). Por isso, em 2002, no Brasil, o Ministério da Saúde determinou a fortificação obrigatória das farinhas de trigo e milho com ferro e ácido fólico, para prevenir a ocorrência de anemia e Defeitos do Tubo Neural (DTN), mediante a RDC n. 344, de 2002, da ANVISA. Essa resolução determinou que cada $100 \mathrm{~g}$ destas farinhas contenham $0,15 \mathrm{mg}$ de ácido fólico; foi negociado com a indústria um prazo de adaptação de 18 meses, até junho de 2004 (28).

Existem poucos trabalhos que avaliaram o consumo de folato durante a gravidez em mulheres brasileiras. Estudos realizados entre os anos de 1990 e 2000 mostram prevalências de consumo inadequado de folato em cerca de 60 a $80 \%$ das gestantes $(29,30,31,32)$. Estudo sobre o consumo alimentar de gestantes adolescentes, em serviço de assistência pré-natal em Fortaleza verificou que as dietas estavam inadequadas - com menos de $70 \%$ de adequação - em relação ao ácido fólico, usando como parâmetro a referência do Institute of Medicine (33).

Porém, esses estudos se limitam, em sua maioria, à região sudeste do Brasil. Estudos em regiões mais pobres são escassos, bem como estudos após a fortificação obrigatória das farinhas de trigo e milho, ocorridas em 2004. Por isso, torna-se importante verificar se o consumo médio permite concluir que a fortificação das farinhas com ácido fólico tem sido uma medida eficaz para aumentar a ingestão 
de ácido fólico e, consequentemente, possibilitar a diminuição da prevalência de defeitos de tubo neural.

\section{JUSTIFICATIVA}

Os defeitos do tubo neural (DTNs) estão entre as mais importantes causas congênitas de morbidade e mortalidade infantil, ocorrendo em 300 mil recémnascidos a cada ano, em todo o mundo. As crianças com DTN podem apresentar paraplegia, bexiga neurogênica, infeccções urinárias, insuficiencia renal, hidrocefalia e cifoescoliose, apenas para citar as manifestações mais graves ou frequentes.

Em junho de 2004, o Ministério da Saúde determinou a fortificação obrigatória das farinhas de trigo e milho com ácido fólico, em um esforço para prevenir defeitos do tubo neural, condições com potencial de prejudicar o desenvolvimento físico e mental das crianças.

A realização deste trabalho se justifica, pois verifica, com alcance regional e nacional, a efetividade da política de fortificação obrigatória de farinhas com ácido fólico na prevenção de defeitos do tubo neural. Ademais, identifica possíveis associações de DTNs com fatores maternos e neonatais, além de determinar o padrão de consumo de folato por gestantes no Vale do Jequitinhonha, Minas Gerais, Brasil, uma das regiões mais pobres do país, nove anos após a obrigatoriedade de fortificação das farinhas com ácido fólico.

Este trabalho contribui para a literatura nacional e internacional, uma vez que poucos países têm publicado estudos sobre a efetividade da fortificação de alimentos na prevenção de defeitos do tubo neural, e também pode subsidiar melhorias nas políticas públicas para prevenção de defeitos do tubo neural no Brasil e em outros países. 


\section{OBJETIVOS}

\subsection{OBJETIVO GERAL}

Avaliar a efetividade da política de fortificação de farinhas de trigo e milho com ácido fólico na redução da prevalência de defeitos do tubo neural no Brasil.

\subsection{OBJETIVOS ESPECÍFICOS}

Estimar a prevalência de defeitos do tubo neural no Brasil antes e depois da fortificação obrigatória das farinhas de trigo e milho com ácido fólico, e identificar possíveis fatores maternos associados à ocorrência de DTNs.

(Artigo 1)

Estimar o padrão de consumo de folato por gestantes no Vale do Jequitinhonha, Minas Gerais, Brasil, e possíveis fatores maternos associados ao baixo consumo.

(Artigo 2) 


\section{METODOLOGIA}

\subsection{METODOLOGIA DO ESTUDO NACIONAL COM DADOS SECUNDÁRIOS}

Trata-se de um estudo transversal retrospectivo populacional, realizado a partir de dados secundários referentes a nascidos vivos e óbitos fetais disponibilizados pelo Sistema de Informações sobre Nascidos Vivos (SINASC) e pelo Sistema de Informações sobre Mortalidade (SIM), respectivamente, ambos gerenciados pelo Ministério da Saúde.

Os casos foram selecionados, em âmbito nacional, em cada sistema, por meio da identificação de anomalias ou más-formações correspondentes a DTNs, segundo a classificação Internacional de Doenças $10^{\text {a }}$ revisão (CID 10): Q00 (anencefalia), Q01 (encefalocele) e Q05 (espinha bífida, que inclui meningocele e mielomeningocele). O Sistema de Informações sobre Nascidos Vivos (SINASC) foi implementado em 1990 e tem um campo específico que possibilita a notificação das anomalias congênitas desde 1999. Até o ano de 2006, contudo, somente um código de anomalia podia ser digitado no banco de dados. A partir desse ano todas as anomalias congênitas descritas podem ser digitadas no SINASC.

Casos de DTNs foram identificados entre os nascidos vivos quando qualquer um dos códigos CID-10 acima mencionados foi registrado nos campos 34 (até 2006) ou 41 (depois de 2007), na Declaração de Nascido Vivo. Para identificar um "caso" DTN entre natimortos, esses mesmos códigos foram pesquisados como causa básica de óbito ou para patologias associadas nas declarações de óbito.

Para realizar o cálculo da prevalência de DTNs, foram considerados apenas os dados dos estados com cobertura acima de 95\% do SINASC (34) e SIM (35), durante o período de 2001 a 2010, a saber: Espírito Santo, Rio de Janeiro, São Paulo, Paraná, Santa Catarina, Rio Grande do Sul, Mato Grosso do Sul e Distrito Federal. O período de busca compreendeu de 2001 a 2010. Os dados obtidos foram exportados e analisados no programa Epi-Info, versão 7.0, e pelo programa Origin 6.0 (Microcal Software Inc.).

As variáveis independentes foram a idade e a escolaridade maternas, assim como o sexo do recém-nascido/natimorto. Para os nascidos vivos também foi analisada a raça do RN. A idade materna foi categorizada em três grupos: mães de 
até 19 anos (adolescentes), de 20 a 34 (adultos jovens) e com idade igual ou superior a 35 anos (mães idosas). Quanto à raça/ cor, os recém-nascidos foram categorizados no SINASC em brancos, pardos, pretos e indígenas. A variável dependente foi a presença de DTN. Nascidos vivos sem informação sobre o resultado (variável dependente, DTN) não entraram na análise. Isso representou $7,5 \%$ dos casos compreendidos no período de 2001-2010. Não houve falta de dados de DTN no sistema SIM (natimortos). Os totais para as variáveis independentes idade, sexo e raça podem ser ligeiramente diferentes devido a dados faltantes.

Os dados foram exportados e analisados no Epi Info TM, versão 7.0, e Origin 6.0 (Microcal Software Inc.). A prevalência de DTN e subtipos (Q00, Q01, Q05) foi estimada para o período anterior (2001-2004) e posterior (2005-2010) à fortificação com ácido fólico. Para a associação testada, as razões de prevalência (RP) foram calculadas considerando um limite de confiança de $95 \%$. Os totais para cada variável podem diferir, devido à falta de dados.

Este estudo foi submetido ao Comitê de Ética da Universidade Estadual de Montes Claros (UNIMONTES) e aprovado sob o protocolo número 3094 (Anexo 8.1).

\subsection{METODOLOGIA DO ESTUDO REGIONAL COM DADOS PRIMÁRIOS}

Trata-se de um estudo transversal entre gestantes assistidas em unidades básicas de saúde de quinze municípios do Vale do Jequitinhonha, Minas Gerais, Brasil. O Vale do Jequitinhonha ocupa 14,5\% da área do Estado de Minas Gerias, e, segundo o Sistema de Informações Hospitalares do Sistema Único de Saúde (SIH/SUS), vinte e nove dos oitenta municípios da região apresentam registro de partos pelo SUS (36).

A amostra de gestantes foi calculada considerando o universo de 12.500 partos registrados no ano de 2010, nos vinte e nove municípios do Vale do Jequitinhonha, MG, os quais possuem registros de partos pelo SUS (36). Considerou-se também a prevalência de ingestão deficiente de folato de $30 \%$ calculada a partir da média de três estudos realizados no Rio de Janeiro $(18,29,31)$ com limite de confiança de $95 \%$ e erro admissível de 4 pontos percentuais. Desse 
modo, calculou-se um número de 485 gestantes como tamanho mínimo da amostra para este estudo.

A investigação em campo foi realizada entre janeiro a dezembro de 2013, com 492 gestantes em unidades básicas de saúde (UBSs) de 15 dos 29 municípios, selecionados pelo critério de realizar pelo menos um parto por dia, ou 30 partos ao mês. Em conjunto, esses 15 municípios realizavam 78\% dos partos na região.

Em cada município, foi selecionada uma amostra de gestantes proporcional ao número de partos registrados pelo SUS. O inquérito foi realizado nas UBSs dos municípios, limitando-se ao máximo de nove UBSs por município. Para municípios que possuíam mais de nove UBSs, foram selecionadas randomicamente 9 UBSs para realização da pesquisa.

As entrevistas foram realizadas por entrevistadores treinados, acompanhados por coordenador de campo. As gestantes foram abordadas durante as reuniões de pré-natal que ocorriam mensalmente nas UBSs, ou em reuniões eletivas. Depois de cada entrevista foi oferecido café-da-manhã.

Os critérios para inclusão de gestantes na pesquisa foram: encontrar-se no terceiro trimestre de gestação no momento da aplicação do questionário e residir em um dos oitenta Municípios do Vale do Jequitinhonha. O critério de exclusão foi: gestante com deficiência cognitiva ou auditiva. Todas as mães foram informadas sobre a pesquisa, sendo solicitada a assinatura do Termo de Consentimento Livre e Esclarecido. Nas UBSs pesquisadas, os médicos também foram entrevistados para verificar a prescrição de medicamentos e/ou suplementos que contenham ácido fólico em sua formulação, caso a gestante não soubesse informar. Os profissionais foram informados sobre a pesquisa, sendo solicitada a assinatura do Termo de Consentimento Livre e Esclarecido (Anexo 8.2).

Para a coleta de dados, foi utilizado um questionário sócio-econômico e de conhecimentos sobre a suplementação com o ácido fólico (Anexo 8.3), previamente testado e readequado após estudo-piloto.

Foram coletadas variáveis demográficas e sócio-econômicas e de participação em programas sociais; dados sobre a gestação atual e atenção prénatal; bem como dados sobre o conhecimento e uso da suplementação do ácido fólico. Para avaliar o consumo de ácido fólico entre essas gestantes, foi aplicado um Questionário de Freqüência Alimentar (QFA) (anexo 8.4), já adaptado à população e 
ao nutriente avaliado, e previamente utilizado em pesquisa anterior (37). Ele foi empregado para coleta de dados referentes à alimentação durante a gestação, e apresenta opções de frequência de consumo de uma série de alimentos selecionados. A lista de alimentos era composta por 76 itens, para os quais são oferecidas porções padronizadas, em medidas caseiras ou unidades de alimentos, que avaliam a quantidade consumida. Para obter uma estimativa de consumo alimentar diário, as frequências referidas de consumo dos alimentos foram convertidas em um equivalente de consumo diário.

Para determinar o tamanho da porção consumida ou a quantidade em gramas $(\mathrm{g})$ ou mililitros $(\mathrm{ml})$ de uma porção caseira pré-estabelecida no questionário de frequência alimentar (QFA), foi utilizada a Tabela para Avaliação de Consumo Alimentar em Medidas Caseiras (38), (anexo 8.5). Para cada um dos 76 itens alimentares, calculou-se o valor em mcg de folato. A tabela de composição de alimentos disponibilizado pelo Instituto Brasileiro de Geografia e Estatística (39) foi utilizada como referência para obtenção da composição nutricional dos alimentos. Uma segunda tabela de composição alimentar, a Tabela de Composição de Alimentos, suporte para decisão nutricional (40), foi consultada quando algum dos alimentos presentes no QFA ou algum nutriente em investigação não estivesse contemplado na TCA/ IBGE. Como terceira opção, os rótulos dos alimentos foram consultados, com o intuito de obter informações nutricionais faltantes.

$\mathrm{Na}$ verificação da adequação do consumo de folato na gravidez, utilizouse como referência a recomendação preconizada pelo Institute of Medicine, que indica a RDA (Recommended Dietary Allowances) de folato de 600mcg para gestantes (26). Utilizou-se, também, o que foi proposto por School e colaboradores (41), que consideravam baixo o consumo de folato inferior a $60 \%$ do recomendado, e, de $61 \%$ a $100 \%$, consumo intermediário. Baseando-se também no estudo de Fonseca et al. (2003) (30), dividiu-se o consumo em três categorias: menor que $360 \mathrm{mcg} /$ dia (<60\% da recomendação), de $360 \mathrm{mcg}$ a $599 \mathrm{mcg} / \mathrm{dia}$ (61\% a $99 \%$ da recomendação), de maior ou igual a $600 \mathrm{mcg}$ ( $100 \%$ ou mais). Também foi verificado se os valores provenientes da fortificação de alimentos atingiam a UL (Tolerable Upper Intake Levels). Os valores de ácido fólico provenientes dos alimentos fortificados e dos suplementos foram convertidos para unidade Equivalente de Folato Dietético (DFE), uma vez que o ácido fólico é mais biodisponível que o folato 
proveniente dos alimentos não fortificados: 1 DFE corresponde a $0,6 \mathrm{mcg}$ de ácido fólico proveniente de alimentos fortificados e/ou de suplementos consumidos com alimento, e é igual a $1 \mathrm{mcg}$ de folato da dieta (26).

Foi verificado, também, o uso de suplementos vitamínicos pelas gestantes. Para estimar a quantidade de ácido fólico proveniente do suplemento, utilizou-se o recomendado por Fonseca e colaboradores (31), assumindo-se um consumo diário de $400 \mathrm{mcg}$ de ácido fólico, dose recomendada para as gestantes e usual nos suplementos vitamínicos.

Os dados do questionário foram digitados no Excel e posteriormente transferidos para o Epiinfo (42), para a análise estatística. No caso das variáveis quantitativas contínuas, como idade e consumo alimentar, calcularam-se as médias, medianas e desvio padrão. Quando necessário, a comparação de médias foi realizada pelo teste ANOVA, utilizando programa Origin 6.0 (Microcal Software Inc.). Para as variáveis discretas, foram calculadas frequências, mediana, desvio padrão, Intervalos de Confiança (95\%) e, para os testes de associação quando apropriado, a Razão de Prevalência (RP), considerando-se o Limite de Confiança de 95\%.

O projeto foi submetido ao Comitê de Ética da Universidade Estadual de Montes Claros (UNIMONTES) e aprovado sob o protocolo número 3094.

\section{RESULTADOS E DISCUSSÃO}

Os resultados e discussão serão apresentados na forma de 02 (dois) artigos traduzidos e padronizados segundo a revista a que foram submetidos para publicação.

O primeiro artigo intitulado: "Effectiveness of mandatory folic acid fortification in the prevention of neural tube defects in Brazil" foi submetido (Anexo 8.6 ) à revista Bulletin of the World Health Organization, de padrão internacional, com sede em Genebra, Suiça. O segundo artigo, intitulado "Folic acid intake by pregnant women from Vale do Jequitinhonha, Brazil, and the contribution of fortified foods", foi aceito (Anexo 8.7) na revista Arquivos Latino-americanos de Nutrición, de padrão internacional, com sede em Caracas, Venezuela. 


\title{
5.1. ARTIGO 1
}

\section{EFFECTIVENESS OF MANDATORY FOLIC ACID FORTIFICATION IN THE PREVENTION OF NEURAL TUBE DEFECTS IN BRAZIL}

\author{
Leonor M. P. Santos \\ Roberto C. R. Lecca \\ Juan J. C. Escalante \\ Mauro N. Sanchez \\ Humberto G. Rodrigues
}

Departamento de Saúde Coletiva, Universidade de Brasília. DF, Brasil. (LMPS; MNS)

Ministério da Saúde, Secretaria de Vigilância em Saúde, Brasília, DF, Brasil. (RCRL; JJCE) Faculdades Integradas Pitágoras de Montes Claros, Montes Claros, MG, Brasil. (HGR)

\section{Corresponding author:}

Leonor Maria Pacheco Santos

SQN 312 bloco G apt 113, CEP 79765-070 Brasília DF, Brazil. Phone: (55 61) 3447-7726.

Email: leopac@unb.br

Key words: Folic acid; Food, fortified; Neural Tube Defects, Brazil

Source s of support: The Brazilian National Research Council (CNPq) partially supported this work (Research Fellowship to LMPS)

Running head: Brazil folic acid prevents neural tube defects

PubMed indexing: Santos, Lecca; Escalante; Sanchez; Rodrigues

Reprints: will not be available from the authors.

\section{List of abbreviations:}

NTDs - Neural Tube Defects

SINASC - Live Births Information System

SIM - Mortality Information System

ANVISA - Brazilian Ministry of Health Regulatory Agency

ICD 10 - International classification of diseases and related health problems $10^{\text {th }}$ revision

$\mathrm{CI}_{95 \%}-95 \%$ Confidence Intervals 


\begin{abstract}
Background: The Brazilian Ministry of Health established the mandatory fortification of wheat and maize flour with iron and folic acid in June 2004, to prevent the occurrence of anemia and neural tube defects, conditions that impair the child's development.
\end{abstract}

Objective: To test the hypothesis that fortification of flours with folic acid contributes to prevent the occurrence of neural tube defects.

Design: Population-based retrospective cross-sectional study to analyze the prevalence of neural tube defects in live births and stillbirths, based on secondary data from national information systems in the pre- (2001-2004) and post-fortification periods (2005-2010). The malformations analyzed, according to the International Classification of Diseases (ICD-10) were: Q00 (anencephaly), Q01 (encephalocele) and Q05 (spina bifida, including meningocele and myelomeningocele). The prevalence of neural tube defects was estimated for the periods before and after the intervention; prevalence ratios and $95 \%$ confidence intervals were calculated.

Results: A total of 12,556,701 births with complete information notified to the Live Births Information System and 142,915 records of fetal deaths reported to the Mortality Information System were analyzed, resulting in the identification of 6,048 cases of neural tube defects among live births and 2,084 fetal deaths with neural tube defects in the period 2001-2010. The prevalence of neural tube defects was $31.6 \%$ lower in the post-fortification period: 0.54/1,000 births (2005-2010), compared to 0.79/1,000 births in the initial period (20012004); (Prevalence Ratio=1.47, $\mathrm{CI}_{95 \%}$ [1.41-1.53]). Lower prevalence was found amongst stillbirths $(-32.7 \%)$ as well as for live births $(-26.3 \%)$, with the largest prevalence change being for anencephaly in the former case $(-34.2 \%)$ and spina bifida in the latter case $(-32.1 \%)$. Large differences in the prevalence of these congenital defects were observed after fortification in children of adolescent mothers (-40.4\%) and in female newborns/ stillborns ($37.6 \%)$.

Conclusions: The results confirm the effectiveness of the folic acid fortification policy in the primary prevention of neural tube defects in Brazil. 


\section{INTRODUCTION}

Neural tube defects (NTDs) are among the most significant congenital causes of morbidity and mortality, occurring in 300,000 newborns each year worldwide (1). They are caused by the abnormal closure of the embryonic neural tube around the 22th to 28th day after conception. The resulting structural defects occur anywhere along the neuraxis and often lead to the exposure of neural tissue, causing severe impairment to the child's physical and mental development $(2,3)$.

Classically, NTDs are divided into two main groups: (a) defects affecting brain structures, such as anencephaly and encephalocele; (b) defects that affect the structures of the spinal cord (spina bifida) $(4,5)$. Anencephaly, also called exencephaly or craniorachischisis, is defined as the complete or partial absence of the brain, caused by a failure of the cephalic neural tube to close $(6,7)$, leading to fetal deaths, stillbirths and neonatal deaths. Spina bifida is characterized by the failure of fusion of the vertebral arches of the spine. This defect can be covered by skin (spina bifida occulta), or be associated with a cystic protrusion, which may contain abnormal meninges and cerebrospinal fluid (meningocele) or elements of the spinal cord and/or nerves (myelomeningocele). Another severe NTD is encephalocele, in which the brain and meninges herniate through a skull defect, especially in the occipital region (1).

Genetic and environmental factors are often implicated in NTDs. The genetic factors include simple gene mutations like Meckel syndrome and chromosomal abnormalities (7). As for environmental factors, NTDs are strongly correlated with low folate intake and also with maternal factors such as age, ethnicity, obesity and the use of antiepileptic drugs $(1,4,7,8)$. Studies show that an extra intake of folic acid in the periconceptional period reduces the risk of occurrence and recurrence of NTDs by 60 to $70 \%$ (9-12). Food fortification with folic acid was shown to be effective and is now mandatory in more than forty countries (13s). After mandatory folic acid fortification NTD prevalence was found to be $0.3 / 1,000$ births in the USA (14), 0.86/1,000 births in Canada (15), 0.98/1000 births in South Africa (16) and 1.0/1,000 births in Chile (17).

In 2002, the Brazilian Ministry of Health regulatory agency, ANVISA, published resolution number 344 establishing the mandatory fortification of wheat and maize flour with iron and folic acid to prevent the occurrence of anemia and neural tube defects (NTDs) in Brazil. 
This resolution determined that every $100 \mathrm{~g}$ of flour must contain $0.15 \mathrm{mg}$ folic acid, and negotiated an 18 month adaptation period with the industry, which expired in June 2004 (18).

Most studies calculate the prevalence of NTDs among live births; however this does not reflect the actual prevalence of these defects, since fetal deaths and stillbirths with NTDs are not accounted for. The prevalence of NTDs in London was 5.3/1,000 among fetal deaths from 8-week pregnancies, while among live births it was much lower, at 2.8/1,000 (19). A similar study was done in Ireland, in which the reported prevalence of NTDs in 8-week miscarriages was 10.8/1,000, while among live births it was 7.1/1,000 (20).

The present study aimed to test the hypothesis that fortification of flour with folic acid reduced the prevalence of NTDs in Brazil among live newborns and stillborn, as well as to identify possible associations with maternal and newborn characteristics.

\section{MATERIALS AND METHODS}

Databases: Since 1970 Brazil has established the public reporting of health data. This study was based on registries from the Live Birth Information System (SINASC) and the Mortality Information System (SIM), both managed by the Brazilian Ministry of Health. The SINASC system was introduced in 1990 and has had a particular field that allows the notification of congenital anomalies since 1999. Up to 2006 only one CID code per birth could be entered in the database, but since then all congenital anomalies present in one child can be recorded in the system.

Study design: Population-based retrospective cross sectional study to analyze the prevalence of neural tube defects in live births and stillbirths, based on secondary data on live births from SINASC and on stillbirths from SIM. The cases were selected from each system by identifying the anomalies which correspond to NTD malformations according to the International Classification of Diseases, 10th revision (ICD-10) namely: Q00 (anencephaly), Q01 (encephalocele) and Q05 (spina bifida, including myelomeningocele and meningocele). An NTD "case" was defined for live births when any of the above mentioned ICD-10 codes were annotated in fields 34 (up until 2006) or 41 (2007 and after) in the Live Birth Declaration. To identify NTD "cases" amongst stillbirths, these same codes were searched for as basic causes of death or associated pathologies on death certificates.

To calculate the prevalence of NTDs, only data from states with over $95 \%$ of births registered in the SINASC (21) and SIM (22) systems were considered. Publicly available data 
for eight states were included: Distrito Federal, Espirito Santo, Mato Grosso do Sul, Paraná, Rio de Janeiro, Rio Grande do Sul, Santa Catarina, São Paulo. The study period was from 2001 to 2010.

Study variables: The independent variables were: flour fortification, maternal age, the sex of the newborn/stillborn and race, analyzed only for live births. Maternal age was categorized into three groups: up to 19 (adolescents), from 20 to 34 (young adults) and 35 or over (older mothers). Regarding race, newborns were categorized in the SINASC systems as white, brown, black or indigenous. The race for stillborn is not classified in the SIM system. The dependent variable was the presence of NTDs. Live births without information regarding the outcome (dependent variable, NTD) did not enter the analysis. This is shown in Figure 1 and represented $7.5 \%$ of all cases from 2001-2010. There was no missing data for NTD in the SIM system (stillbirths). Totals for the independent variables age, sex and race, may differ slightly due to missing data.

Data analysis: Data were exported and analyzed using the Epi Info ${ }^{\mathrm{TM}}$, version 7.0, and Origin 6.0 (Microcal Software Inc.). The prevalences of NTDs and subtypes Q00, Q01 and Q05 were estimated for the periods before (2001-2004) and after (2005-2010) fortification with folic acid. For the association tests the prevalence ratios (PR) were calculated considering $95 \%$ confidence limits.

This study was submitted to the Ethics Committee of Universidade Estadual de Montes Claros (UNIMONTES) and approved under protocol \# 3094.

\section{RESULTS}

After the application of inclusion criteria (Figure 1), a total of 12,556,701 live birth records from the Live Births Information System (SINASC) were studied and 142,915 fetal deaths records from the Mortality Information System (SIM), in the eight selected states from January 2001 to December 2010. This is equivalent to $45.5 \%$ of the total records for the entire country. Among these records, 8,132 cases of NTDs were disclosed in the period: 6,048 cases among live births and 2,084 NTDs related to fetal deaths.

From 2001 to 2004 - prior to the mandatory fortification of flours with folic acid - the prevalence of NTDs was 0.79/1,000 births; in contrast, for 2005-2010 period, the prevalence of NTDs was $31.6 \%$ lower at $0.54 / 1,000$ births. Before the intervention the prevalence was $0.57 / 1,000$ for live births and $17.74 / 1,000$ for stillbirths. The post-fortification prevalence of 
NTDs amongst live births was $0.42 / 1,000$ births, or $26.3 \%$ lower, while the prevalence of NTDs among stillbirths fell to $11.94 / 1,000$ deaths, or $32.7 \%$ lesser (Table 1).

A lower prevalence of all types of NTD was found in the post-fortification period compared to the pre-fortification years, both for live births and for fetal deaths (Table 2). The largest prevalence change was for anencephaly (-34.2\%) amongst stillbirths, while the biggest difference for live births was for spina bifida $(-32.1 \%)$.

The prevalence of NTDs according to maternal and fetal characteristics prior to the intervention showed that the highest prevalence of NTDs was amongst newborns and stillborns of mothers aged up to 19 (0.94/1,000 births/ stillbirths). In other words the probability of cases of NTD was 1.34 higher for the adolescent mothers (Table 3). The prevalence of NTDs was found to be higher in female than in male newborns/ stillborns $0.93 / 1,000$ vis-à-vis $0.65 / 1,000$, or a $40 \%$ higher probability of a NTD case in female offspring. As for ethnicity, the highest prevalence of NTDs was found for indigenous newborns $(0.82 / 1,000)$; however, this figure derives from just 13 cases of NTD in newborns from indigenous women. After mandatory fortification the largest changes observed were $40.4 \%$ lower prevalence for the offspring of adolescent mothers and $37.6 \%$ lower for female newborns/ stillborns.

The comparability of the populations under study is crucial. Table 4 displays the characteristics of the population sub-sets included before and after mandatory fortification of flours with folic acid. The comparison shows a non-significant difference for the variable sex of newborn or stillborn and small differences for maternal age and race of the newborn.

\section{DISCUSSION}

This population-based retrospective study disclosed a prevalence of neural tube defects in Brazil of $0.79 / 1,000$ births before fortification with folic acid, while after the interventions it was $31.6 \%$ lower, at $0.54 / 1,000$ births, thus confirming the study hypothesis. Two similar studies were conducted in Brazil and both reported lower prevalence of neural tube defects after folic acid fortification. The first one was part of the Latin American Collaborative Study of Congenital Malformations, ECLAMC, and was based on data from 19 hospitals, which correspond to $1 \%$ of all births in Brazil (23). The second was a crosssectional study focusing only on spina bifida and comparing the prevalence in 2004 and 2006, pre- and post-fortification, respectively (24). Our study is broader in many aspects: in terms of 
follow up period (2001-2010), population coverage (45.5\% of all births in the country), data retrieval (13 million records from SINASC and 142 thousand records of fetal deaths from SIM) and covers the most common types of neural tube defects (Q00- anencephaly, Q01encephalocele and Q05-spina bifida - including myelomeningocele and meningocele).

The value of $31.6 \%$ is higher than that reported in the ECLAMC study, which found prevalence of $1.04 / 1,000$ before and $0.81 / 1,000$ after fortification, corresponding to $22.1 \%$ lower prevalence (23). The difference may be attributed to the methodological approaches.

In the present population-based retrospective study, the prevalence of spina bifida was 0.28/1,000 births before fortification with folic acid and 0.19/1,000 births after mandatory fortification, or a $32.1 \%$ lower prevalence. This value is somewhat lower than the $39.1 \%$ reduction of spina bifida reported by a cross-sectional study of birth defects in Brazil, comparing 2004 SINASC database, before mandatory fortification (prevalence of 0.23/1000 births) and 2006, after fortification (prevalence of 0.14/1000 births) (24) The difference can be explained, possibly, because the study has been done in just two years, 2004 and 2006, differently from our study with a larger period both before and after mandatory fortification with folic acid. Another hypothesis is due to the fact the article of Orioli et al (2011) covered states with poor SINASC coverage, while our study is more robust, as it included data from states with over $95 \%$ notification coverage in the SINASC (21).

The 31.6\% lower prevalence of NTDs in Brazil after mandatory fortification with folic acid, reported here, is similar to the $30.5 \%$ decline found in South Africa (16). However, it is higher than the $19 \%$ lower prevalence reported in the USA (14), but lower than the reduction of $40 \%$ found in Chile (17), than the $46 \%$ reported in Canada (15s) and the drop of 58\% (anencephaly) and 60\% (spina bifida-total) in Argentina (23), countries that have also introduced mandatory fortification of flour with folic acid. A recent meta-analysis of eight population-based studies examining folic acid food fortification arrived to an estimated reduction in NTDs prevalence of $46 \%$ (11). More than forty countries implemented mandatory fortification, but just a few have evaluated its effectiveness (11).

As for the occurrence of specific types of NTD, this study showed that anencephaly was the most common type, followed by spina bifida and encephalocele. This finding differs from other studies, which have found spina bifida to be the most frequent, followed by anencephaly and encephalocele (23). This difference may be due to the inclusion of NTDs among fetal deaths or stillbirths, whereas other studies have analyzed only the prevalence of NTDs among live births, where the prevalence of spina bifida may be higher. However, as 
pointed out before, data from live births alone may underestimate the prevalence of NTDs $(19,20)$.

The prevalence of NTDs was found to be higher in female newborns and stillborn, which is also reported in the literature $(15,25-27)$. The epidemiological link between the observed frequencies and the sex is very complex. A possible reason for this phenomenon is the fact that, for the neural tube, the female fetus requires more human chorionic gonadotropin than males, and deficiencies of this hormone can increase the risk of such malformation. The maximum concentration of human chorionic gonadotropin occurs between the 40th and 50th day after fertilization, which reinforces the hypothesis, since the neural tube closes in the first four weeks of embryonic development $(28,29)$

In the present study NTDs prevalence was highest among indigenous neonates, closely followed by black newborns, a finding that is corroborated by other studies. Ray and collaborators (30) conducted a retrospective survey of women from Ontario, Canada, with the objective of verifying the association between the ethnicity/race of pregnant women and newborns and the risk of NTDs. They found that the risk of NTDs was higher in women and newborns of indigenous origin. Shaw and colleagues (31) conducted a survey in California to investigate the comparative risk of NTDs among Hispanic and white women; they found that the risk of NTDs in pregnancy was two times higher for women and newborns of Mexican descent than it was for white women. However, the prevalence of NTDs amongst indigenous children reported here may not be reliable, since it was based on a very small number of observations.

The effect of maternal age on the risk of NTDs is generally considered small. When there is an association between age and NTDs, the prevalence tends to be higher in the youngest and oldest age brackets (32). This phenomenon was observed in the present investigation, in which the prevalence was highest for mothers up to age 19 and over 35 . One potential explanation for the prevalence of NTDs in young mothers is that teenage pregnancy poses a greater nutritional risk, because their diet may not adequately meet the combined nutritional requirements for the adolescents' growth and fetal growth during pregnancy, which would partly explain the high number of cases of NTDs in this age group. Another hypothesis is that young women are less likely to ingest supplements with folic acid (33). One possibility for older mothers is that the transplacental flow of folic acid and other vitamins declines with age. 
Public reporting of health data is crucial to help administrative staff and health planners to take the best possible decisions for promoting health and wellbeing (34) and to foster a culture of accountability, transparency, and efficiency (35). The completeness and reliability of SINASC and SIM data are essential for this study. Public reporting of demographic and health care data in Brazil began in the 1970s, and after the implementation of the National Public Health System (SUS) in the mid-1980s, many efforts were undertaken to improve the system's quality. Several reports point the improvements in quality of information (34, 36-38), including a case control study (39) and active searches for unreported births and deaths $(40,41)$. Recently UNICEF acknowledged the political commitment to improving health information systems in Brazil, especially about births and infant deaths, which was supported by public funding (42). One sign of the robustness of these databases is the large number of studies based on secondary data from SINASC, SIM and SIH (Information System about Hospitalizations): between 1900 and 2006 almost 300 papers were published in Brazil and abroad in high impact journals (43).

A possible source of bias is pregnancy termination due to anencephaly. Abortion is illegal in Brazil but individual court rulings may override the law. However, the bureaucracy involved in such cases means the actual number of abortions is low, and is very unlikely to affect the study results.

\section{CONCLUSION}

The results are in accordance with previous studies and confirm the effectiveness of the folic acid fortification policy in the primary prevention of neural tube defects in Brazil. This study showed significantly lower prevalence of NTDs between the periods before and after mandatory fortification of wheat and maize flour with folic acid.

\section{ACKNOWLEDGMENTS}

The authors' responsibilities were as follows. LMPS: designed the study; JJCE and MNS: contributed to the study design; RCRL: conducted the data extraction; HGR and RCLR performed data checking and the statistical analyses; HGR, LMPS, MNS, RCRL and JJCE: wrote and took responsibility for the final content of the manuscript. All authors had no conflicts of interest to declare. The Ministry of Health paid salaries to JJCE and RCRL, but 
had no role in the design and conduct of the study, collection, analysis and interpretation of data, or preparation, review, or approval of the manuscript.

\section{REFERENCES}

1. Botto LD, Moore CA, Khoury MJ, Erickson JD (1999) Neural tube defects - Review articles. N Engl J Med 341:1509-1519.

2. Grillo E, Silva RJM (2003) Defeitos de tubo neural e hidrocefalia congênita: porque conhecer as suas prevalências? J Pediatr (Rio J) 79: 105-106.

3. Tamura T, Picciano MF (2006) Folate and human reproduction. Am J Clin Nutr 83: $993-1016$

4. Molloy AM (2005) The role of folic acid in the prevention of neural tube defects. Trends Food Sci Technol 16: 241-245.

5. Townsend CM, Beauchamp RD, Evers BM, Mattox KL (2009) Sabiston Tratado de cirurgia. Rio de Janeiro: Elsevier 2344 p.

6. Pitkin RM (2007) Folate and neural tube defects. Am J Clin Nutr 85(suppl): 285S-8S.

7. Pulikkunnel ST, Thomas SV (2005) Neural Tube Defects: Pathogenesis and Folate Metabolism. J Assoc Physicians India 53: 127-135.

8. Frey L, Hauser WA (2003) Epidemiology of neural tube defects. Epilepsia 44: 4-13.

9. Laurence KM, James N, Miller MH, Tennant GB, Campbell H (1981) Double-blind randomised controlled trial of folate treatment before conception to prevent recurrence of neural-tube defects. Br Med J (Clin Res Ed) 282: 1509-1511.

10. Czeizel AE, Dudas I (1992) Prevention of the first occurrence of neural-tube defects by periconceptional vitamin supplementation. N Engl J Med 327(26): 1832-1835.

11. Blencowe H, Cousens S, Modell B, Lawn J (2010) Folic acid to reduce neonatal mortality from neural tube disorders. Int J Epidemiol 39 (suppl 1): i110-i121.

12. De-Regil LM, Fernández-Gaxiola AC, Dowswell T, Peña-Rosas JP (2010) Effects and safety of periconceptional folate supplementation for preventing birth defects. Cochrane Database Syst Rev 10: CD007950.

13. Santos LMP, Pereira MZ (2007) The effect of folic acid fortification on the reduction of neural tube defects. Cad Saude Publica 23(1):17-24. 
14. Honein MA, Paulozzi LJ, Mathews TJ, Erickson JD. Wong LY (2001) Impact of folic acid fortification of the US food supply on the occurrence of neural tube defects. JAMA 285: 2981-2986.

15. De Wals P, Fassiatou Tairou F, Allen MIV, Uh SH, Lowry RB, Sibbald B, Evans JA, Van den Hof MC, Zimmer P, Crowley M, Fernandez B, Lee NS, Niyonsenga T (2007). Reduction in Neural-Tube Defects after Folic Acid Fortification in Canada. N Engl J Med 357:135-42.

16. Sayed AR, Bourne D, Pattinson R, Nixon J, Henderson B (2008) Decline in the prevalence of neural tube defects following folic acid fortification and its cost-benefit in South Africa. Birth Defects Res A Clin Mol Teratol 82:211-16.

17. Hertrampf E, Cortés F (2004) Folic acid fortification of wheat flour: Chile. Nutr Rev 62 (6 Pt 2): S44-8.

18. Brasil. Ministério da Saúde (2002). Agência Nacional de Vigilância Sanitária ANVISA. Resolução - RDC no 344, de 13 de dezembro de 2002. Diário Oficial [da] República Federativa do Brasil, Brasília, DF. Available: http://www.anvisa.gov.br/legis/resol/2002/344_02rdc.htm. Accessed 15 June 2014.

19. Creasy MR, Alberman ED (1976) Congenital malformations of the central nervous system in spontaneous abortions. J Med Genet 13: 9-16.

20. Machenry JCRM, Nevin NC, Merrett JD (1979) Comparison of central nervous system malformation in spontaneous abortions in Northern Ireland and south-east England. Br Med J (Clin Res Ed) 1:1395-1397.

21. Brasil. Ministério da Saúde (2014) Razão entre nascidos vivos informados e estimados,

Brasil 2000-2011.

Available: http://tabnet.datasus.gov.br/cgi/idb2012/a17b.htm. Accessed 15 June 2014.

22. Brasil. Ministério da Saúde (2014) Razão entre óbitos informados e estimados, Brasil 2000-2011. Available: http://tabnet.datasus.gov.br/cgi/idb2012/a1801b.htm. Accessed 15 June 2014.

23. Lopez-Camelo JS, Castilla EE, Orioli IM (2010) Folic acid flour fortification: impact on the frequencies of 52 congenital anomaly types in three South American countries. Am J Med Genet A 152A: 2444-2458.

24. Orioli IM, Lima do Nascimento R, López-Camelo JS, Castilla EE (2011) Effects of folic acid fortification on spina bifida prevalence in Brazil. Birth Defects Res A Clin Mol Teratol. 91(9): 831-835. 
25. Stevenson RE, Allen WP, Pai SG, Best R, Seaver LH, et al. (2000) Decline in Prevalence of Neural Tube Defects in a High-Risk Region of the United States. Pediatrics 106(4): 677-683.

26. Pacheco SS, Souza AI, Vidal AS, Guerra GV; Batista-Filho M, et al. (2006) Neural tube defects prevalence in newborn infants in the women care center of the Instituto Materno Infantil Prof. Fernando Figueira, IMIP: 2000-2004. Rev Bras Saude Mater Infant 6(Suppl 1): 35-42.

27. Afshar M, Golalipour MJ, Farhud D (2006) Epidemiologic aspects of neural tube defects in South East Iran. Neurosciences 11(4): 289-292.

28. Janerich DT (1975) Female excess in anencephaly and spina bifida: possible gestations influences. Am J Epidemiol 101(1): 70-76.

29. Serrato FF (2006) Defectos de tubo neural en hijos de mujeres expuestas a contaminantes ambientales em La zona metropolitana de Guadalajara 2003-2005. Arch Neurocien 11(3): 146-152.

30. Ray JG, Vermeulen MJ, Meier C, Cole DEC, Wyatt PR (2004) Maternal ethnicity and risk of neural tube defects: a population-based study. CMAJ 171(4): 343-345.

31. Shaw GM, Velie EM, Wasserman CR (1997) Risk for neural tube defect-affected pregnancies among women of Mexican descent and white women in California. Am J Public Health 87(9): 1467-1471.

32. Fujimori E, Baldino CF, Sato APS, Borges ALV, Gomes MN (2013) Prevalência e distribuição espacial de defeitos do tubo neural no Estado de São Paulo, Brasil, antes e após a fortificação de farinhas com ácido fólico. Cad Saude Publica 29(1): 145-154.

33. Langley-Evans SC, Langley-Evans AJ (2002) Use of folic acid supplements in the first trimester of pregnancy. J R Soc Promot Health 122(3): 181-186.

34. Mello Jorge MH, Laurenti R, Gotlieb SLD (2007) Quality analysis of Brazilian vital statistics: the experience of implementing the SIM and SINASC systems. Cien Saude Colet 12(3): 643-654.

35. Sharma K, Metzler IS, Chen S, Mayer Jr JE, Meara JG (2012) Public reporting of health care data: A new frontier in quality improvement. Bull Am Coll Surg 97(6):613

36. Theme Filha MM; Gama SGN; Cunha CB; Leal MC (2004) Reliability of birth certificate data (SINASC) in Rio de Janeiro, Brazil, 1999-2001. Cad Saude Publica 20 (supl.): S83-S91, 2004. 
37. Romero DE, Cunha CB (2007) Evaluation of quality of epidemiological and demographic variables in the Live Births Information System, 2002. Cad Saude Publica 23(3): 701-714.

38. Andrade CLT, Szwarcwald CL (2007) Socio-spatial inequalities in the adequacy of Ministry of Health data on births and deaths at the municipal level in Brazil, 20002002. Cad Saude Publica 23(5): 1207-1216.

39. Almeida MF, Alencar GP, França Jr. I, Novaes HMD, Siqueira AAF, et al. (2006) Validation of birth certificates based on data from a case-control study. Cad Saude Publica 22(3): 643-652.

40. Façanha MC, Pinheiro AC, Fauth S, Lima AWDBC, Silva VLP, et al. (2003) Active searches for deaths in cemeteries in the Metropolitan Area of Fortaleza, 1999 to 2000. EpidemiolServ Saude 12(3): 2003.

41. Szwarcwald CL, Morais Neto OL, Frias PG, Souza Jr PRB, Escalante JJC, et al. (2011) Busca ativa de óbitos e nascimentos no Nordeste e na Amazônia Legal: estimação das coberturas do SIM e do SINASC nos municípios brasileiros. In: Ministério da Saúde. Saúde Brasil 2010; uma análise da situação de saúde. DF: Ministério da Saúde. p. 79-98. Available: http://bvsms.saude.gov.br/bvs/publicacoes/saude_brasil_2010.pdf, Accessed 28 June 2014.

42. United Nations Children's Fund (2010) Good practices in integrating birth registration into health systems (2000-2009). Case Studies: Bangladesh, Brazil, Gambia and Delhi, India. New York: UNICEF, Working Paper. Available: http://www.unicef.org/protection/Birth_Registration_Working_Paper(2).pd f , Accessed 28 June 2014

43. Drumond EF, Machado CJ, Vasconcelos MR, França E (2009) The use of secondary data from SIM, Sinasc, and SIH in Brazilian scientific production between 1990 and 2006. R bras Est Pop 26(1): 7-19. 


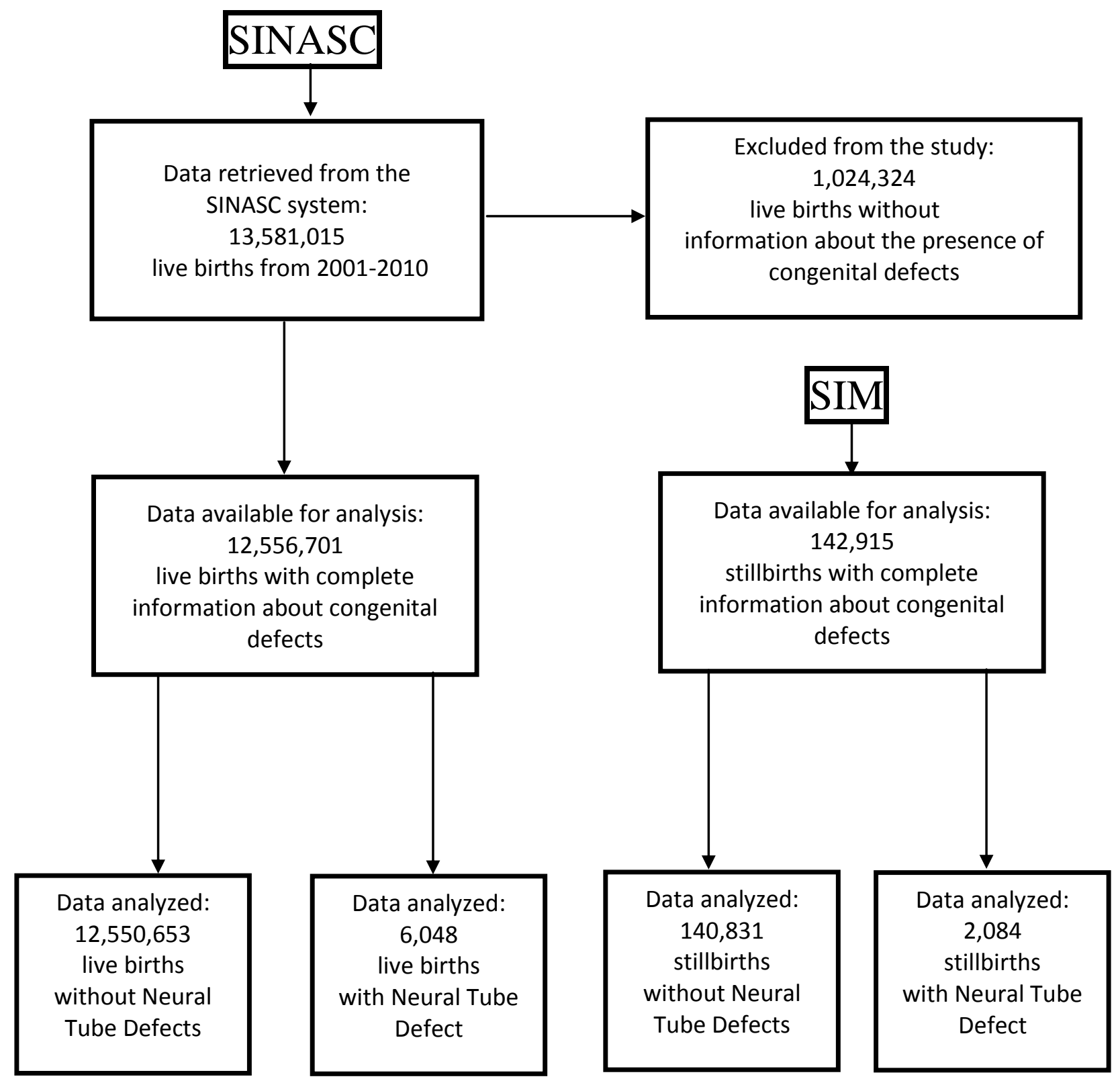

Figure 1. Flow diagram and selection criteria for inclusion of live birth records from SINASC system and stillbirth records from SIM system. Brazil, 2001-2010. 
Table 1: Prevalence of neural tube defects in live births and stillbirths before and after the mandatory fortification of flours with folic acid. Brazil 2001 to 2010.

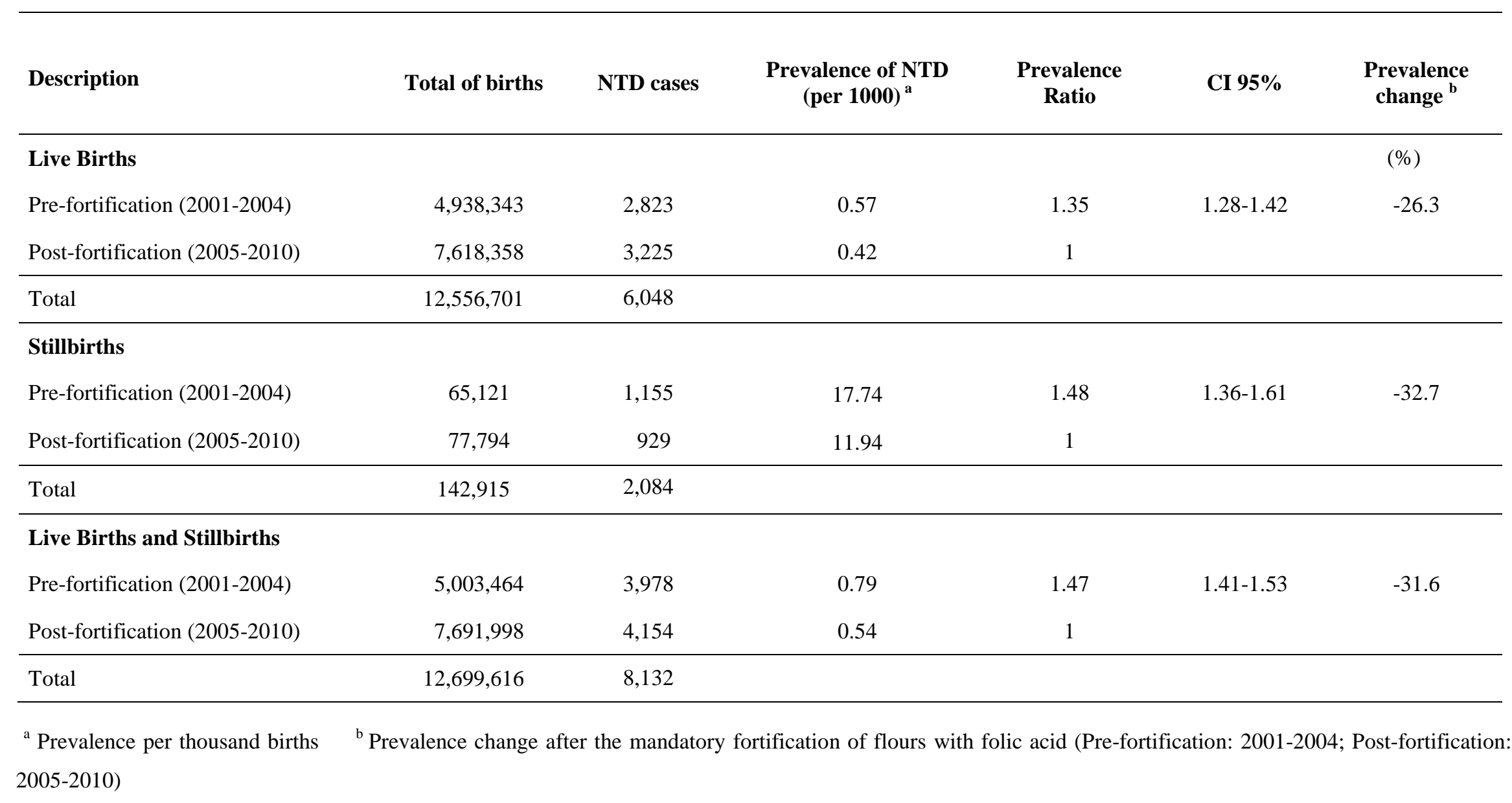


Table 2: Prevalence of neural tube defects according to the different types before and after the mandatory fortification of flours with folic acid. Brazil, 2001 to 2010.

\begin{tabular}{|c|c|c|c|c|c|c|c|c|c|c|c|c|c|c|c|}
\hline \multirow{3}{*}{$\begin{array}{l}\text { Classification } \\
\text { of the Neural } \\
\text { Tube Defect }\end{array}$} & \multicolumn{5}{|c|}{ Live Births } & \multicolumn{5}{|c|}{ Stillbirths } & \multicolumn{5}{|c|}{ Live Births and Stillbirths } \\
\hline & \multicolumn{2}{|c|}{$\begin{array}{l}\text { Pre-fortification } \\
(n=4,938,343)\end{array}$} & \multicolumn{2}{|c|}{$\begin{array}{l}\text { Post-fortification } \\
\quad(n=7,618,358)\end{array}$} & \multirow{2}{*}{ 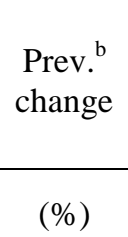 } & \multicolumn{2}{|c|}{$\begin{array}{l}\text { Pre-fortification } \\
\qquad(n=65,121)\end{array}$} & \multicolumn{2}{|c|}{$\begin{array}{l}\text { Post-fortification } \\
\qquad(n=77,794)\end{array}$} & \multirow{2}{*}{$\begin{array}{c}\text { Prev. }^{b} \\
\text { change }\end{array}$} & \multicolumn{2}{|c|}{$\begin{array}{l}\text { Pre-fortification } \\
(n=5,003,464)\end{array}$} & \multicolumn{2}{|c|}{$\begin{array}{l}\text { Post-fortification } \\
\quad(n=7,696,152)\end{array}$} & \multirow{2}{*}{$\begin{array}{r}\begin{array}{l}\text { Prev. } \\
\text { change }\end{array} \\
(\%)\end{array}$} \\
\hline & Cases & Prev. $^{\text {a }}$ & Cases & Prev. $^{\text {a }}$ & & Cases & Prev. $^{\text {a }}$ & Cases & Prev. $^{\text {a }}$ & & Cases & Prev. ${ }^{\text {a }}$ & Cases & Prev. ${ }^{\mathrm{a}}$ & \\
\hline Anencephaly & 1,035 & 0.21 & 1,264 & 0.16 & -23.8 & 1,056 & 16.22 & 830 & 10.67 & -34.2 & 2,091 & 0.41 & 2,094 & 0.27 & -34.1 \\
\hline Encephalocele & 388 & 0.08 & 479 & 0.06 & -25.0 & 39 & 0.60 & 45 & 0.58 & -3.3 & 427 & 0.09 & 524 & 0.07 & -22.2 \\
\hline Spina bifida & 1,400 & 0.28 & 1,482 & 0.19 & $-32,1$ & 80 & 1.23 & 68 & 0.87 & -29.3 & 1,480 & 0.29 & 1,550 & 0.20 & -31.0 \\
\hline
\end{tabular}

${ }^{a}$ Prevalence per thousand births $\quad{ }^{b}$ Prevalence change after the mandatory fortification of flours with folic acid (Pre-fortification: 2001-2004; Post-fortification: 2005-2010) 
Table 3: Prevalence of neural tube defects according to maternal and fetal characteristics for live births and stillbirths before and after the mandatory fortification of flours with folic acid. Brazil, 2001 to 2010.

\begin{tabular}{|c|c|c|c|c|c|c|c|c|c|}
\hline \multirow{2}{*}{ Characteristic } & \multicolumn{4}{|c|}{ Live Births and Stillbirths 2001-2004 } & \multicolumn{4}{|c|}{ Live Births and Stillbirths 2005-2010 } & \multirow{2}{*}{$\begin{array}{c}\text { Prevalence } \\
\text { change }^{d}\end{array}$} \\
\hline & $\begin{array}{c}\text { Total of } \\
\text { births }\end{array}$ & NTD cases & Prevalence $^{\text {a }}$ & $\operatorname{PR}\left(\mathrm{CI}_{95 \%}\right)^{\mathrm{c}}$ & $\begin{array}{c}\text { Total of } \\
\text { births }\end{array}$ & NTD cases & $\underset{\mathbf{a}}{\text { Prevalence }}$ & $\operatorname{PR}\left(\mathrm{CI}_{95 \%}\right)^{\mathrm{c}}$ & \\
\hline \multicolumn{10}{|l|}{ Maternal age } \\
\hline Up to 19 & 971,805 & 915 & 0.94 & $1.34(1.2-1.4)$ & $1,343,162$ & 754 & 0.56 & $1.1(1.0-1.2)$ & $-40.4 \%$ \\
\hline 20 to 34 & $3,488,203$ & 2,449 & 0.70 & 1 & $5,427,445$ & 2,753 & 0.51 & 1 & $-27.1 \%$ \\
\hline Over 35 & 526,589 & 371 & 0.70 & $1.0(0.9-1.1)$ & 908,714 & 474 & 0.52 & $1.0(0.9-1.1)$ & $-25.7 \%$ \\
\hline \multicolumn{10}{|c|}{ Sex of newborn or stillborn } \\
\hline Female & $2,437,225$ & 2,264 & 0.93 & $1.4(1.3-1.5)$ & $3,750,704$ & 2,171 & 0.58 & $1.2(1.1-1.3)$ & $-37.6 \%$ \\
\hline Male & $2,560,657$ & 1,656 & 0.65 & 1 & $3,941,972$ & 1918 & 0.49 & 1 & $-24.6 \%$ \\
\hline \multicolumn{10}{|c|}{ Race of newborn ${ }^{b}$} \\
\hline White & $3,505,035$ & 1,983 & 0.57 & $1.1(1.0-1.2)$ & $5,438,913$ & 2,303 & 0.42 & $1.1(1.0-1.2)$ & $-26.3 \%$ \\
\hline Brown & 880,425 & 439 & 0.50 & 1 & $1,683,009$ & 671 & 0.40 & 1 & $-20.0 \%$ \\
\hline Black & 122,622 & 73 & 0.60 & $1.2(0.9-1.5)$ & 171,825 & 76 & 0.42 & $1.1(0.9-1.4)$ & $-30.0 \%$ \\
\hline Indigenous & 15,930 & 13 & 0.82 & $1.6(0.9-2.8)$ & 21,940 & 11 & 0.50 & $1.25(0.7-2.3)$ & $-39.0 \%$ \\
\hline
\end{tabular}

${ }^{a}$ Prevalence per thousand births $\quad{ }^{b}$ Race is not available for stillbirths $\quad{ }^{c} \mathrm{PR}=$ Prevalence Ratio

${ }^{\mathrm{d}}$ Prevalence change after the mandatory fortification of flours with folic acid (Pre-fortification: 2001-2004; Post-fortification: 2005-2010) 
Table 4: Characteristics of the populations under study before and after the mandatory fortification of flours with folic acid. Brazil 2001 to 2010.

\begin{tabular}{lrrrr}
\hline \multirow{2}{*}{ Characteristics } & \multicolumn{2}{c}{ Live Births/ Stillbirths 2001-2004 } & \multicolumn{2}{c}{ Live Births/ Stillbirths 2005-2010 } \\
\cline { 2 - 5 } & Study population & Characteristic & Study population & Characteristic \\
\hline Maternal age & & $(\%)$ & & $(\%)$ \\
up to 19 & 971,805 & 19.5 & $1,343,162$ & 17.5 \\
20 to 34 & $3,488,203$ & 70,0 & $5,427,445$ & 70.7 \\
over 35 & 526,589 & 10.6 & 908,714 & 11.8 \\
Total & $\mathbf{4 , 9 8 6 , 5 9 7}$ & $\mathbf{1 0 0 . 0 0}$ & $\mathbf{7 , 6 7 9 , 3 2 1}$ & $\mathbf{1 0 0 . 0 0}$ \\
\hline Sex of newborn or stillborn & & & & 48.8 \\
Female & $2,437,225$ & 48.8 & $3,750,704$ & 51.2 \\
Male & $2,560,657$ & 51.2 & $3,941,972$ & $\mathbf{1 0 0 . 0 0}$ \\
Total & $\mathbf{4 , 9 9 7 , 8 8 2}$ & $\mathbf{1 0 0 . 0 0}$ & $\mathbf{7 , 6 9 2 , 6 7 6}$ & 74.3 \\
\hline Race of newborn ${ }^{\text {a }}$ & & & & 23.0 \\
White & $3,505,035$ & 77.4 & $5,438,913$ & 2.3 \\
Brown & 880,425 & 19.5 & $1,683,009$ & 0.3 \\
Black & 122,622 & 2.7 & 171,825 & $\mathbf{1 0 0 . 0 0}$ \\
Indigenous & 15,930 & 0.3 & 21,940 & $\mathbf{7 , 3 1 5 , 6 8 7}$ \\
Total & $\mathbf{4 , 5 2 4 , 0 1 2}$ & $\mathbf{1 0 0 . 0 0}$ & & \\
\hline
\end{tabular}

${ }^{\mathrm{a}}$ Race is not available for stillborn 


\subsection{ARTIGO 2}

FOLIC ACID INTAKE BY PREGNANT WOMEN FROM VALE DO

JEQUITINHONHA, BRAZIL, AND THE CONTRIBUTION OF FORTIFIED FOODS

RODRIGUES, H.G.; GUBERT, M.B.; SANTOS L.M.P

\section{Humberto Gabriel Rodrigues*}

Faculdades Integradas Pitágoras de Montes Claros, Montes Claros, MG, Brasil.

\section{Muriel Bauermann Gubert}

Universidade de Brasília, Departamento de Nutrição, Faculdade de Ciências da Saúde, Brasília, DF, Brasil.

\section{Leonor Maria Pacheco Santos}

Universidade de Brasília, Departamento de Saúde Coletiva, Faculdade de Ciências da Saúde, Brasília, DF, Brasil.

*Autor para correspondência:

\section{Humberto Gabriel Rodrigues}

Faculdades Integradas Pitágoras de Montes Claros, Montes Claros, MG, Brasil.

Av. Professora Aida Mainartina Paraiso, 80, Ibituruna, Montes Claros - MG, Brasil CEP: 39408-007 Telefone: (5538) 3212-1002 
SUMMARY. Folate deficiency can result in irreversible health damage, such as the neural tube defects. The aim of this article is to determine the folate intake of pregnant women in Vale do Jequitinhonha, Minas Gerais state, Brazil, one of the poorest regions in the country. A descriptive, cross-sectional study was done in 2013 with 492 pregnant women attending the basic health units run by the public health service (Sistema Único de Saúde, SUS) in 15 municipalities. A standard questionnaire was used to gather the data, which included socioeconomic indicators and a food frequency questionnaire. The data were analyzed and compared statistically based on prevalence ratios and $95 \%$ confidence intervals. The prevalence of inadequate folate intake was associated with some socioeconomic factors: it was higher amongst the low income and less educated women, in younger women and those who had fewer meals per day. The prevalence of inadequate folate intake in the diet was $94.7 \%$ when the contribution of food fortification was not considered, $49.2 \%$ taking into account fortified foods, and $17.1 \%$ considering food folate, fortified foods, and supplementation with folic acid. We conclude that fortifying foods with folic acid at the current levels reduces the inadequacy of folate intake in the diet, but not enough to assure safe levels and to meet the nutritional requirements of pregnant women in Brazil.

KEYWORDS: folic acid, neural tube defects, Brazil.

RESUMO. Consumo de ácido fólico por Gestantes do Vale do Jequitinhonha, Brasil, e a contribuição dos alimentos fortificados. A deficiência de folato pode acarretar prejuízos irreversíveis como os Defeitos do Tubo Neural. O objetivo deste artigo é determinar o padrão de consumo de folato por gestantes no Vale do Jequitinhonha, Minas Gerais, Brasil, uma das regiões mais pobres do país. A pesquisa descritiva do tipo transversal foi realizada com 492 gestantes atendidas em Unidades Básicas de Saúde do SUS em 15 municípios do Vale do Jequitinhonha no ano de 2013. Para a coleta de dados foi utilizado um questionário padronizado, que inclui um questionário socioeconômico e inquérito de frequência alimentar. Os dados foram analisados e comparados estatisticamente através de razão de prevalências e intervalo de confiança de $95 \%$. A prevalência de consumo insuficiente de folato mostrou-se associada com alguns fatores socioeconômicos: foi maior em gestantes com baixa renda, de baixa escolaridade e em gestantes mais jovens e que realizavam menos refeições por dia. Observou-se que a prevalência de consumo insuficiente de folato na dieta foi de $94,7 \%$ desconsiderando a inclusão de alimentos fortificados, 49,2\% considerando a dieta com alimentos fortificados e 17,1\% considerando a dieta, a fortificação e a suplementação medicamentosa com ácido fólico. Conclui-se que a fortificação de alimentos com ácido fólico nos níveis atuais reduz a inadequação do consumo na dieta, mas não é suficiente para suprir as necessidade e garantir os níveis seguros da oferta deste nutriente entre gestantes brasileiras.

PALAVRAS-CHAVE: Ácido fólico, Defeitos do Tubo Neural, Brasil. 


\section{INTRODUCTION}

Folate is an essential micronutrient necessary for the normal metabolism of the organism. Its deficiency can result in irreversible health effects. The population groups most prone to folate deficiency are pregnant women, pre-school-age and school-age children, breastfeeding women and female adolescents. In these groups there is an increased pace of cell growth and development, resulting in higher folate requirement $(1,2)$.

During pregnancy, folate is important for the increased growth of red blood cells, the expansion of the uterus, the growth of the placenta and the fetus, and the prevention of preterm births. Folate deficiency could be associated with complications during pregnancy, including hypertension syndrome, hemorrhaging, miscarriages, and cardiovascular diseases (3).

However, folate deficiency is most often cited as the primary risk factor for neural tube defects (NTDs). NTDs are among the most significant congenital causes of morbidity and mortality, occurring in 300,000 newborns each year worldwide (4). They are caused by the abnormal closure of the embryonic neural tube around the 22rd to 28th day after conception. The resulting structural defects occur anywhere along the neuraxis and often lead to the exposure of neural tissue. Children with NTDs may have paraplegia, neurogenic bladder, urinary tract infections, renal failure, hydrocephalus and kyphoscoliosis, to name just the most severe or frequent manifestations (5).

Genetic factors are associated with the causes of NTDs. These include simple gene mutations like Meckel syndrome and chromosomal abnormalities such as trisomy 13 and 18, and polymorphisms of genes associated with folate metabolism, such as the gene associated with methylenetetrahydrofolate reductase (MTHFR) (6).

Folic acid prevents NTDs because it is a source of carbon for nucleotide synthesis and a variety of methylation reactions. Reduced levels in the organism are associated with a buildup of homocysteine, which in turn produces an enzymatic alteration in MTHFR, causing NTDs $(4,7)$.

The serious nature of neural tube defects and the associated morbidity and mortality makes it even more important to assure adequate folic acid intake by improving the diet, fortification and/or supplementation with this vitamin. Studies show that the extra intake of folic acid in the periconceptional period reduces the risk of occurrence and recurrence of NTDs by $60 \%$ to $70 \%$ (7). 
Folic acid supplementation prior to pregnancy has been recommended since 1992 (8, 9). The Institute of Medicine's daily recommended intake of $600 \mathrm{mcg}$ is often hard to achieve with a natural diet (without fortified foods), which supplies around $250 \mathrm{mcg} / \mathrm{day}$ for a total daily energy intake of 2,200 Kcal (2). In response, in 2002 the Brazilian Ministry of Health established the mandatory fortification of wheat and maize flour with iron and folic acid to prevent the occurrence of anemia and neural tube defects, through Anvisa resolution RDC 344. This resolution determined that every $100 \mathrm{~g}$ of flour must contain $0.15 \mathrm{mg}$ folic acid, and negotiated an 18 month adaptation period with the industry, which expired in June 2004 (10).

Little research has been done into the effect of folate intake by Brazilian women during pregnancy. The studies done in the 1990s and in the first decade of this century show a prevalence of inadequate folate intake by pregnant women around 60-80\% (11-13). A study into the food consumption of pregnant adolescents by a prenatal center in Fortaleza found that their diets were poor, containing less than $70 \%$ the recommended folic acid intake, based on the Institute of Medicine reference level (14).

However, most of these studies have been done in the south-east of Brazil. Studies in poorer parts of the country are scarce, and very few have been done since wheat and maize flour fortification became mandatory in 2004. This is why it is important to ascertain whether the average intake is raised enough by flour fortification with folic acid to effectively increase the supply of folic acid and consequently result in lower prevalence of neural tube defects.

This article aims to evaluate the intake of folate by pregnant women from Vale do Jequitinhonha, one of the poorest parts of the world, nine years after the mandatory fortification of flour with folic acid was introduced in Brazil. The aim is to ascertain whether folate consumption levels are adequate and what are the main sources of the folate consumed, as well as its associated factors, providing inputs for public policies designed to reduce NTDs in such vulnerable population groups.

\section{MATERIALS AND METHODS}

This was a cross-sectional study of pregnant women receiving prenatal care at basic health units in 15 municipalities in Vale do Jequitinhonha, Minas Gerais, Brazil. Vale do Jequitinhonha covers $14.5 \%$ of the area of Minas Gerais state, and 29 of the 80 municipalities in the region record their deliveries in the Hospital Information System run by the public health service (Sistema Único de Saúde, SUS). 
The sample size was calculated considering the total of 12,500 deliveries registered in 2010 in Vale do Jequitinhonha (15) and an expected prevalence of 30\% of inadequate intake, calculated from the average of three studies done in Rio de Janeiro $(1,11,12)$, a confidence limit of $95 \%$, and an acceptable error of 4 percentage points. As such, the minimum sample size for this study was calculated as 485 pregnant women.

The field study was done at basic health units from 15 municipalities selected because they had an average of one delivery a day, or 30 a month, in 2012. Together, these municipalities comprise $78 \%$ of all the region's deliveries. Two to nine health units were selected randomly from each municipality for inclusion in the study.

The inclusion criteria for the study were women in the third trimester of pregnancy and residents in one of the 80 municipalities in Vale do Jequitinhonha. The exclusion criteria were pregnant women with cognitive or auditory deficiency. All the women were informed about the research, and were asked to sign an informed consent form. At the health clinics included in the study, the doctors were also interviewed to find out whether they prescribed medications and/or supplements that contained folic acid, in cases where the women did not know. They were also informed about the study and asked to sign an informed consent form.

A questionnaire was used to gather socioeconomic data and information about folic acid supplementation, which had previously been tested and adjusted after a pilot study. The questions were asked by trained interviewers, who were supervised by a field coordinator. Whenever possible, the women were approached when they attended their prenatal group visits, which took place every month at the clinic, or by individual appointments.

Demographic and socioeconomic data were collected, as well as information on the women's participation in social welfare programs. Data were also gathered on the current pregnancy and the prenatal care received, as well as the women's familiarity with and use of folic acid supplementation. To assess their folate intake, we employed a food frequency questionnaire (FFQ), adapted to the population group and nutrient evaluated, which had already been used in a previous research (16). It was used to obtain data on habitual diet during pregnancy, and presented options about the frequency of consumption of a number of selected foods. The 76 food items on the list were presented in standard portions, using household measurements or individual units, to calculate the quantities consumed. In order to estimate daily intake, the stated frequencies of the foods consumed were converted into their daily folate equivalent. 
To determine the portions consumed or the size of a household portion from the food frequency questionnaire (FFQ) in grams (g) or milliliters $(\mathrm{ml})$, a table for evaluating food consumption in household measurements was used (17). The quantity of folate in mcg was calculated for each of the 76 food items listed. The food composition table published by Instituto Brasileiro de Geografia e Estatística (18) was used to obtain the nutritional composition of the foods. A second food composition table (19) was consulted when one of the foods on the FFQ or some food under investigation was not contained on the TCA/IBGE table. Finally, the nutritional information on the packaging of the foods consumed was consulted to fill any remaining information gaps. Nutritional labelling is mandatory in all manufactures foods in Brazil.

In order to verify the adequacy of folate intake during pregnancy, the Institute of Medicine's recommended dietary allowance (RDA) of $600 \mathrm{mcg}$ folate was used (9). We also adopted proposal of classifying below or $60 \%$ of the recommended daily intake as low and $61 \%$ to $100 \%$ as intermediate (20). Also, drawing on the work of Fonseca and collaborators (12), intake was divided into three categories: less than $360 \mathrm{mcg} /$ day ( $<60 \%$ of RDA), 360 $\mathrm{mcg}$ to $599 \mathrm{mcg} / \mathrm{day}(61 \%$ to $99 \%$ of RDA), and $600 \mathrm{mcg} / \mathrm{day}$ or more (100\% or more of RDA). We also ascertained whether the intake values obtained from food fortification reached the tolerable upper intake level (UL). The folic acid values from fortified foods and supplements were converted into dietary folate equivalent (DFE), since the bioavailability of folic acid is greater than the folate from unfortified foods. As such, 1 DFE was taken as corresponding to $0.6 \mathrm{mcg}$ folic acid from fortified foods and/or supplements consumed with food, and was the equivalent of $1 \mathrm{mgc}$ food folate (9).

The pregnant women's use of vitamin supplements was also checked. To estimate the quantity of folic acid in the supplements, the method recommended by of Fonseca and collaborators (12) was adopted, which assumes a daily intake of $400 \mathrm{mcg}$ of folic acid, the dose recommended for pregnant women and normally found in vitamin supplements.

The data were subject to statistical analysis with Epiinfo (2007) software package (21). In the case of the continuous variables, such as age and food consumption, the means, medians and standard deviation were calculated. When necessary, the averages were compared using ANOVA with the Origin 6.0 software package (Microcal Software Inc.). For the categorical variables, the frequencies, standard deviation and 95\% confidence intervals were calculated, and for the association tests, when appropriate, the prevalence ratio (PR) was calculated, considering a $95 \%$ confidence limit. 
The project was submitted to the ethics committee of the State University of Montes Claros (Universidade Estadual de Montes Claros, UNIMONTES) and approved under protocol no. 3094.

\section{RESULTS}

Interviews were conducted with 492 pregnant women in the last trimester of pregnancy who were receiving prenatal care at the basic health units under study, all run by the public health service (SUS), in 15 municipalities in Vale do Jequitinhonha, Brazil.

The average age of the pregnant women studied was 25.3 ( $\mathrm{SD}=6.2$ years); the youngest was 13 and the oldest was 43; there were $20.3 \%$ of adolescent mothers. Most of the women declared to have brown or black skin $(78.6 \%)$ and lived with a partner $(72.3 \%)$; $32.7 \%$ of women reached only primary education.

The majority of the women had a household income of up to one minimum wage (66.7\%). The mean household income was 1.44 times the minimum wage. $45.7 \%$ of the women received the federal government's conditional cash transfer benefit, "Bolsa Família", and the average length of participation in this program was 3.7 years (Table 1).

It was the first pregnancy for $39.8 \%$ of the women interviewed, and $66.1 \%$ of the women had had fewer than six prenatal visits (Table 1). Most of the women (92.7\%) did not smoke before getting pregnant, and $96.1 \%$ were not smoking while they were pregnant. $74.3 \%$ of the women said they did not drink alcohol before they got pregnant, and $96.5 \%$ said they did not drink during pregnancy.

Concerning micronutrient supplementation, the vast majority said they heard of folic acid supplements from health professionals. However, only $4.8 \%$ started supplementation before becoming pregnant, $34.3 \%$ during the first month of pregnancy and $53.9 \%$ said they started later (Table 1). The women mentioned other supplements they used, which included ferrous sulfate $(67.1 \%)$ and multivitamins $(2.6 \%)$.

Around $40.0 \%$ of the women $(n=195)$ had received nutritional guidance from health professionals, $150(76.3 \%)$ of these during pregnancy, most $(80.0 \%)$ with the aim of ensuring a healthy pregnancy. The others said they had received nutritional guidance in order to help them lose $(6.7 \%)$ or gain $(7.7 \%)$ weight, or for other motives $(4.6 \%)$. Two of the women were unable to answer these questions $(1.0 \%)$. 
According to the food frequency questionnaire (FFQ), the pregnant women's average folate intake was 609.1 DFE/day, with a standard deviation of 419.5 DFE/day. As for the tolerable upper intake level (UL) of folate, which is based on the concentration of folic acid from food fortification or supplements, it was found that 91 of the women (18.4\%) reached the UL for folic acid, which is $1,000 \mathrm{mcg}$. However, the prevalence of insufficient folate intake (below the RDA of $600 \mathrm{mcg}$ ) was found to be $94.7 \%$, considering only food folate, without fortification. This figure dropped to $49.2 \%$ after inclusion of the fortified foods the women ingested, and $17.1 \%$ when their diet as a whole was taken, plus supplement use (Table 2).

Some socioeconomic and pregnancy factors associated with a low folate intake (Table 2) were lower educational level ( $\mathrm{PR}=1.8\left[\mathrm{CI}_{95 \%}\right.$ 1.1-3.1]), low household income ( $\mathrm{PR}=2.0$ $\left[\mathrm{CI}_{95 \%}\right.$ 1.3-3.0]), teenage mothers (PR $1.7\left[\mathrm{CI}_{95 \%}\right.$ 1.1-2.4]) and few meals per day $\left(\mathrm{PR}=1.3\left[\mathrm{CI}_{95 \%} 1.1-1.2\right]\right)$.

According to the FFQ, all the women in the sample consumed foods containing wheat flour, maize flour and their derivatives fortified with folic acid. Table 3 shows the average folate consumed per food source, both fortified and not. The most widely consumed fortified foods were pasta (median 64.6 DFE/day), "French bread" (white bread rolls) and sliced bread (median 40.7 DFE/day), savory pastries (median 18.9 DFE/day) and cake (median 7.1 DFE/day). The most consumed unfortified food sources of folate were beans (median 151.6 DFE/day), oranges (median 20.6 DFE/day), milk (median 12.5 DFE/day) and fruit juice (median 9.6 DFE/day).

\section{DISCUSSION}

The prevalence of inadequate folate intake encountered in the study was $94.7 \%$, considering only the natural food sources of folate, without taking food fortification into account. A study in Rio de Janeiro found a prevalence of $63.6 \%$ inadequate folate intake (11). Two other Brazilian studies have reported prevalence of inadequate folate intake of between $50 \%$ and $80 \%$ (12). The largest study published on the consumption of folate by pregnant women in Brazil involved 1,180 adolescents from the municipality of Rio de Janeiro and the inadequacy reached $75.0 \%$ (13).

The higher prevalence of insufficient folate intake encountered in this study could be attributed to the characteristics of the area under study, which has one of the lowest socio- 
economic levels in the country. One of the clear indicators of the degree of poverty in the region is the fact that the most of the pregnant women were living in households that had an income of up to one minimum wage. This degree of economic hardship is normally associated with greater difficulty in maintaining a balanced diet (22). Another indicator is the fact that almost half the women received the federal government's conditional cash transfer benefit, "Bolsa Família", with most of them having been on this benefit for an average of 3.7 years.

When the folate from fortified foods was considered, the prevalence of inadequacy dropped to $49.2 \%$ of the pregnant women. Similar results were found by Pereira (16), who reported a 51.9\% prevalence of insufficient folate intake amongst pregnant women, even taking into account their consumption of foods fortified with folic acid. Finally, the prevalence of inadequacy dropped to $17.1 \%$ when folate intake was calculated by adding the folate from food, from fortified foods and from supplements.

These results indicate there have been some positive changes since the introduction of mandatory fortification of wheat and maize flour with folic acid in 2002 (10), in that the prevalence of inadequate folate intake is lower than it would be, without the consumption of fortified foods.

Adolescence was the age group found to have the highest prevalence of insufficient folate intake: twice higher than the women over 35 years of age. A similar pattern was observed by Mezzomo et al. (1), who found that young mothers (aged under 23) were more susceptible to folate deficiency and therefore presented a higher risk of neural tube defects. Despite the higher folate requirement amongst this age group, because of the pace of cell growth and development, their eating habits are poor, and they do not consume much in the way of fruit and vegetables (14).

Low income seems to be a risk factor for low folate intake during pregnancy, as well as having fewer meals a day. This could be explained by the women's limited financial means, making it hard for them to buy food, so their diets are poor and their access to the most basic means of subsistence at such a delicate stage of life as pregnancy is restricted (22).

As for education, this study points to a higher prevalence of folate intake below the RDA in pregnant women with a lower educational primary level, corroborating the findings of Lima et al. (11). Less schooling implies less access to information, lower income, and consequently more limited access to food and fewer communication resources, hampering access to health services. Education influences a person's understanding of food and nutrition, which has an impact on their food preferences and their habitual diet (14). 
The prevalence of inadequate folate intake was higher for the women who had not planned their pregnancy and who said they had not heard of folic acid. These data reinforce the importance of raising awareness amongst pregnant women about the importance of improving their diet before and during the first weeks of pregnancy and getting periodic check-ups.

In this study the vast majority of the pregnant women took supplements that contained folic acid. However, over half started this supplementation after the recommended period, thereby limiting its protective effect against neural tube defects caused by the closing of the embryonic neural tube around the $22^{\text {nd }}$ to $28^{\text {th }}$ day after conception (5). The small percentage of the women who took periconceptional folate was also significant: just $4.8 \%$ took the supplement before pregnancy, which is similar to the findings of a previous study by Mezzomo et al.(1), who found this prevalence to be 4.3\%. In developed countries, studies indicate that around $40 \%$ of pregnant women use periconceptional folic acid supplements (2324). This shows the importance of adopting measures such as food fortification, which increase folic acid intake not just before and during pregnancy, but in women of childbearing age, serving as a kind of universal supplementation.

This study findings indicate there is a strong correlation between socio-economic factors and insufficient folate intake. The fortified foods found to contribute to the folate intake of the pregnant women from Vale do Jequitinhonha were pasta, white bread rolls and sliced bread. This shows that fortifying foods with folic acid is an important measure for preventing NTDs in Brazil, especially in poor regions like Vale do Jequitinhonha.

\section{CONCLUSIONS}

We conclude that fortifying foods with folic acid at the current levels reduces the inadequacy of folate intake in the diet, but not enough to assure safe and adequate levels and meet the nutritional requirements of pregnant women in Brazil.

\section{ACKNOWLEDGEMENTS}

We thank the financial support from the National Research Council (CNPq), Brazil, contract number: 481364/2011. 


\section{REFERENCES}

1. Mezzomo CLS, Garcias GL, Sclowitz ML, Sclowitz IT, Brum CB, Fontana T, et al. Prevenção de defeitos do tubo neural: prevalência do uso da suplementação de ácido fólico e fatores associados em gestantes na cidade de Pelotas, Rio Grande do Sul, Brasil. Cad Saúde Pública 2007; 23:2716-26.

2. Vitolo MR. Nutrição: da gestação à adolescência. Rio de Janeiro: Reichmann \& Affonso Editores; 2003.

3. Torrens C, Brawley L, Anthony, FW, Dance, CS, Dunn R, Jackson AA, Poston L, Hanson MA. Folate Supplementation During Pregnancy Improves Offspring Cardiovascular Dysfunction Induced by Protein Restriction. Hypertension. 2006; 47: 982-987.

4. Kondo A, Kamihira O, Ozawa, H. Neural tube defects: Prevalence, etiology and prevention. Int J Urol. 2009; 16:49-57.

5. Grillo E, Silva RJM. Defeitos de tubo neural e hidrocefalia congênita: porque conhecer as suas prevalências? J Pediatr (Rio de J) 2003; 79:105-6.

6. Pulikkunnel ST, Thomas SV. Neural Tube Defects: Pathogenesis and Folate Metabolism. JAPI. 2005; 53: 127-135.

7. Safi J, Joyeux L, Chalouhi GE: Periconceptional folate deficiency and implications in neural tube defects. J Pregnancy 2012, 2012:295083.

8. Centers for Disease Control and Prevention. Recommendations for the use of folic acid to reduce the number of case of spina bifida and other neural defects. MMWR Recomm Rep 1992; 41(RR-14):1-7.

9. Institute of Medicine. Dietary reference intakes for thiamin, riboflavin, niacin, vitamin B6, folate, vitamin B12, pantothenic acid, biotin and coline. Washington DC: National Academy Press; 2000.

10. Brasil. Ministério da Saúde (2002). Agência Nacional de Vigilância Sanitária ANVISA. Resolução - RDC no 344, de 13 de dezembro de 2002. Diário Oficial [da] República Federativa do Brasil, Brasília, DF. Available: http://www.anvisa.gov.br/legis/resol/2002/344_02rdc.htm. Accessed 15 June 2014.

11. Lima HT, Saunders C, Ramalho A. Ingestão dietética de folato em gestantes do município do Rio de Janeiro. Rev Bras Saúde Matern Infant 2002; 2: 303-11. 
12. Fonseca VM, Sichieri R, Basílio L, Ribeiro LVC. Consumo de folato em gestantes de um hospital público do Rio de Janeiro. Rev Bras Epidemiol 2003; 6:319-27.

13. Barros DC, Pereira RA, Gama SGN, Leal MC. O consumo alimentar de gestantes adolescentes no Município do Rio de Janeiro. Cad Saúde Pública. 2004; 20(1:S1219):121-9.

14. Azevedo DV, sampaio HAC. Consumo alimentar de gestantes adolescentes atendidas em serviço de assistência pré-natal. Rev Nutr. 2003; 16:273-80.

15. Brasil. Ministério da Saúde (2010) Proporção de partos hospitalares, Brasil 2010. Available: http://tabnet.datasus.gov.br/cgi/deftohtm.exe?idb2012/f07.def. Accessed 15 June 2013.

16. Pereira MZ. Consumo alimentar em gestantes e os possíveis efeitos da fortificação obrigatória de farinhas com ácido fólico na ocorrência de defeitos de tubo neural no Distrito Federal.2007. 122 f. Dissertação (Mestrado em Nutrição Humana) Universidade de Brasília, Brasília, 2007.

17. Pinheiro ABV, Lacerda EMA, Benzecry EH, Gomes MCS, Costa VM. Tabela para avaliação de consumo alimentar em medidas caseiras. São Paulo: Editora Atheneu; 2004.

18. Instituto Brasileiro de Geografia e Estatística (IBGE). Pesquisa de orçamentos Familiares. Tabela de Composição Nutricional dos Alimentos Consumidos no Brasil. Rio de Janeiro: IBGE; 2011.

19. Philippi ST. Tabela de Composição de Alimentos: suporte para decisão nutricional. 2. ed. Brasília: Editora Gráfica Coronário, 2002; 1:135 p.

20. Scholl TO, Hediger ML, Scholl JI, Khoo CS, Fisher RL. Dietary and serum folate: their influence on the outcome of pregnancy. Am J Clin Nutr 1996; 63:520-5.

21. Epi Info (TM) [computer program] Version 3.4. Database and statistics software for public health professionals. Centers for Disease Control and Prevention (CDC), 2007.

22. Fisberg RM, Marchioni DML, Cardoso MRA. Estado nutricional e fatores associados ao déficit de crescimento de crianças frequentadoras de creches públicas do Município de São Paulo, Brasil. Cad. Saúde Pública. 2004; 20(3): 812-817.

23. Feldkamp M, Friedrichs M, Marti K. Folic acid awareness, Knowledge, and consumption among women of childbearing age in Utah, 1998-2000. Am J Med Genet. 2002; 107:67-69. 
24. Jong-Van Den Berg LT; Hernandez-Diaz, S; Werler M.M; Louik C; Mitchell AA. Trends and predictors of folic acid awareness and periconceptional use in pregnant women. Am J Obstet Gynecol. 2005; 192:121-8. 
Table 1: Characteristics of the pregnant women included in the study, who received healthcare at basic health units run by the Brazilian public health service . Vale do Jequitinhonha, Brazil, 2013

\begin{tabular}{|c|c|c|c|}
\hline Characteristic & Category & No. of women & Percentage $\%$ \\
\hline $\begin{array}{l}\text { Maternal age }{ }^{\mathrm{a}} \\
\text { (years) }\end{array}$ & $\begin{array}{l}10-19 \\
20-34 \\
35-45 \\
\text { not informed }\end{array}$ & $\begin{array}{r}100 \\
346 \\
43 \\
3 \\
\end{array}$ & $\begin{array}{r}20.3 \\
70.3 \\
8.8 \\
0.6 \\
\end{array}$ \\
\hline $\begin{array}{l}\text { Ethnicity }{ }^{\text {a }} \\
\text { (self-declared skin color) }\end{array}$ & $\begin{array}{l}\text { brown or black } \\
\text { white } \\
\text { yellow }\end{array}$ & $\begin{array}{c}387 \\
86 \\
19 \\
\end{array}$ & $\begin{array}{r}78.6 \\
17.5 \\
3.9 \\
\end{array}$ \\
\hline Marital status $^{\text {a }}$ & $\begin{array}{l}\text { with partner } \\
\text { without partner } \\
\text { not informed }\end{array}$ & $\begin{array}{r}356 \\
135 \\
1 \\
\end{array}$ & $\begin{array}{r}72.3 \\
27.4 \\
0.2 \\
\end{array}$ \\
\hline Education $^{\text {a }}$ & $\begin{array}{l}\text { primary } \\
\text { secondary } \\
\text { higher } \\
\text { not informed }\end{array}$ & $\begin{array}{r}161 \\
294 \\
33 \\
4 \\
\end{array}$ & $\begin{array}{r}32.7 \\
59.7 \\
6.7 \\
0.8 \\
\end{array}$ \\
\hline $\begin{array}{l}\text { Household income } \\
\text { (minimum wage) }\end{array}$ & $\begin{array}{l}\text { up to one } \\
\text { between one and two } \\
\text { more than two }\end{array}$ & $\begin{array}{r}328 \\
103 \\
61 \\
\end{array}$ & $\begin{array}{l}66.7 \\
20,9 \\
12,4 \\
\end{array}$ \\
\hline $\begin{array}{l}\text { Receives cash benefit a } \\
\text { (Bolsa Família) }\end{array}$ & $\begin{array}{l}\text { ves } \\
\text { no }\end{array}$ & $\begin{array}{l}225 \\
267 \\
\end{array}$ & $\begin{array}{l}45.7 \\
54.3 \\
\end{array}$ \\
\hline Number of meals a dav ${ }^{a}$ & $\begin{array}{l}\text { up to three } \\
\text { more than three }\end{array}$ & $\begin{array}{l}138 \\
354 \\
\end{array}$ & $\begin{array}{l}28.0 \\
72.0 \\
\end{array}$ \\
\hline Number of pregnancies ${ }^{a}$ & $\begin{array}{l}\text { one } \\
\text { two } \\
\text { three } \\
\text { more than three }\end{array}$ & $\begin{array}{r}196 \\
147 \\
89 \\
60\end{array}$ & $\begin{array}{l}39.8 \\
29.9 \\
18.1 \\
12.2\end{array}$ \\
\hline Number of prenatal visits ${ }^{a}$ & $\begin{array}{l}\text { fewer than six } \\
\text { six or more }\end{array}$ & $\begin{array}{l}325 \\
167 \\
\end{array}$ & $\begin{array}{l}66.1 \\
33.9 \\
\end{array}$ \\
\hline Pregnancy planning $^{a}$ & $\begin{array}{l}\text { ves, pregnancy planned } \\
\text { no, pregnancy not planned } \\
\text { not informed }\end{array}$ & $\begin{array}{r}210 \\
279 \\
3 \\
\end{array}$ & $\begin{array}{r}42.7 \\
56.7 \\
0.6 \\
\end{array}$ \\
\hline Smoked before pregnancy ${ }^{a}$ & $\begin{array}{l}\text { ves } \\
\text { no }\end{array}$ & $\begin{array}{r}36 \\
456 \\
\end{array}$ & $\begin{array}{r}7.3 \\
92.7 \\
\end{array}$ \\
\hline Smoking during pregnancy ${ }^{a}$ & $\begin{array}{l}\text { yes } \\
\text { no }\end{array}$ & $\begin{array}{r}19 \\
473 \\
\end{array}$ & $\begin{array}{r}3.9 \\
96.1\end{array}$ \\
\hline $\begin{array}{l}\text { Alcohol consumption } \\
\text { before pregnancy }\end{array}$ & $\begin{array}{l}\text { ves } \\
\text { no }\end{array}$ & $\begin{array}{l}127 \\
365 \\
\end{array}$ & $\begin{array}{l}25.8 \\
74.2 \\
\end{array}$ \\
\hline $\begin{array}{l}\text { Alcohol consumption } \\
\text { during pregnancy }{ }^{a}\end{array}$ & $\begin{array}{l}\text { ves } \\
\text { no }\end{array}$ & $\begin{array}{r}18 \\
474 \\
\end{array}$ & $\begin{array}{r}3.6 \\
96.4\end{array}$ \\
\hline $\begin{array}{l}\text { Family history of } \\
\text { neural tube defects a }\end{array}$ & $\begin{array}{l}\text { ves } \\
\text { no } \\
\text { not informed } \\
\end{array}$ & $\begin{array}{r}25 \\
457 \\
10 \\
\end{array}$ & $\begin{array}{r}5.1 \\
92.9 \\
2.0 \\
\end{array}$ \\
\hline $\begin{array}{l}\text { Familiarity with } \\
\text { folic acid }^{\mathrm{a}}\end{array}$ & $\begin{array}{l}\text { ves } \\
\text { no }\end{array}$ & $\begin{array}{r}440 \\
52 \\
\end{array}$ & $\begin{array}{l}89.4 \\
10.6 \\
\end{array}$ \\
\hline $\begin{array}{l}\text { Source of information } \\
\text { about folic acid }^{b}\end{array}$ & $\begin{array}{l}\text { health professionals } \\
\text { media } \\
\text { friends }\end{array}$ & $\begin{array}{r}403 \\
20 \\
17 \\
\end{array}$ & $\begin{array}{r}91.6 \\
4.5 \\
3.9 \\
\end{array}$ \\
\hline $\begin{array}{l}\text { Start of folic acid } \\
\text { supplementation }\end{array}$ & $\begin{array}{l}\text { before pregnancy } \\
\text { during the first month } \\
\text { after the first month } \\
\text { not informed }\end{array}$ & $\begin{array}{r}21 \\
151 \\
237 \\
31 \\
\end{array}$ & $\begin{array}{r}4.8 \\
34.3 \\
53.9 \\
7.0\end{array}$ \\
\hline $\begin{array}{l}\text { Received nutritional guidance } \\
\text { during pregnancy }{ }^{\text {a }}\end{array}$ & $\begin{array}{l}\text { ves } \\
\text { no }\end{array}$ & $\begin{array}{l}195 \\
297\end{array}$ & $\begin{array}{l}39.6 \\
60.4 \\
\end{array}$ \\
\hline
\end{tabular}


Table 2: Origin of folate consumed and prevalence of inadequate folate intake according to socioeconomic and pregnancy-related factors. Vale do Jequitinhonha, 2013.

\begin{tabular}{|c|c|c|c|c|c|c|}
\hline \multirow{2}{*}{ Origin of folate } & \multicolumn{4}{|c|}{ Folate Intake (DFE/day) $^{\mathbf{a}}$} & \multirow[b]{2}{*}{$\mathbf{P R}^{\mathbf{b}}$} & \multirow[b]{2}{*}{$\mathbf{C I}_{\mathbf{9 5} \%}$} \\
\hline & $<360$ & 361-599 & $>600$ & Inadequa & & \\
\hline $\begin{array}{l}\text { Origin of folate consumed } \\
\text { diet } \\
\text { diet }+ \text { fortification } \\
\text { diet }+ \text { fortification }+ \text { supplementation }\end{array}$ & $\begin{array}{l}353 \\
80 \\
23\end{array}$ & $\begin{array}{l}113 \\
162 \\
61\end{array}$ & $\begin{array}{l}26 \\
250 \\
408\end{array}$ & $\begin{array}{l}94.7 \% \\
49.2 \% \\
17.1 \%\end{array}$ & $\begin{array}{c}5.5 \\
2.9 \\
1\end{array}$ & $\begin{array}{l}4.6-6.7 \\
2.3-3.6\end{array}$ \\
\hline Socioeconomic and pregnancy & \multicolumn{4}{|c|}{ Folate Intake (DFE/day) ${ }^{\text {a }}$} & & \\
\hline factors & $<360$ & 361-599 & $>600$ & Inadequa & $\mathbf{P R}^{\mathrm{b}}$ & $\mathbf{C I}_{\mathbf{9 5} \%}$ \\
\hline $\begin{array}{l}\text { Maternal age } \\
10-19 \\
20-34 \\
35-44 \\
\end{array}$ & $\begin{array}{l}16 \\
62 \\
4\end{array}$ & $\begin{array}{c}57 \\
118 \\
14\end{array}$ & $\begin{array}{c}31 \\
166 \\
25\end{array}$ & $\begin{array}{l}69.0 \% \\
52 . .0 \% \\
41.8 \%\end{array}$ & $\begin{array}{c}1.7 \\
1.2 \\
1\end{array}$ & $\begin{array}{l}1.1-2.4 \\
0.9-1.3(\mathrm{NS})\end{array}$ \\
\hline $\begin{array}{l}\text { Ethnicity (skin color) } \\
\text { white } \\
\text { black / brown } \\
\text { yellow }\end{array}$ & $\begin{array}{l}14 \\
55 \\
2\end{array}$ & $\begin{array}{c}27 \\
131 \\
4\end{array}$ & $\begin{array}{c}45 \\
198 \\
13\end{array}$ & $\begin{array}{l}47.6 \% \\
48.4 \% \\
31.5 \%\end{array}$ & $\begin{array}{c}1.5 \\
1.5 \\
1\end{array}$ & $\begin{array}{l}0.7-3.0 \text { (NS) } \\
0.8-3.0 \text { (NS) }\end{array}$ \\
\hline $\begin{array}{l}\text { Marital status } \\
\text { has a partner } \\
\text { does not have a partner }\end{array}$ & $\begin{array}{l}57 \\
22\end{array}$ & $\begin{array}{c}127 \\
48 \\
\end{array}$ & $\begin{array}{c}172 \\
66 \\
\end{array}$ & $\begin{array}{l}51.6 \% \\
51.4 \%\end{array}$ & $\begin{array}{l}1 \\
1\end{array}$ & $0.8-1.2(\mathrm{NS})$ \\
\hline $\begin{array}{l}\text { Education } \\
\text { primary } \\
\text { secondary } \\
\text { higher } \\
\end{array}$ & $\begin{array}{l}17 \\
57 \\
3\end{array}$ & $\begin{array}{c}72 \\
88 \\
7 \\
\end{array}$ & $\begin{array}{c}72 \\
149 \\
23 \\
\end{array}$ & $\begin{array}{l}55.3 \% \\
49.3 \% \\
30.3 \% \\
\end{array}$ & $\begin{array}{c}1.8 \\
1.3 \\
1\end{array}$ & $\begin{array}{l}1.1-3.1 \\
0.8-2.2(\mathrm{NS})\end{array}$ \\
\hline $\begin{array}{l}\text { Household income (minimum wage) } \\
\text { up to one } \\
\text { between one and two } \\
\text { more than two }\end{array}$ & $\begin{array}{l}62 \\
24 \\
3 \\
\end{array}$ & $\begin{array}{l}120 \\
33 \\
14\end{array}$ & $\begin{array}{l}146 \\
46 \\
44\end{array}$ & $\begin{array}{l}55.5 \% \\
55.3 \% \\
27.9 \% \\
\end{array}$ & $\begin{array}{l}2.0 \\
2.0 \\
1\end{array}$ & $\begin{array}{l}1.3-3.0 \\
1.3-3.0\end{array}$ \\
\hline $\begin{array}{l}\text { Receives cash benefit (Bolsa Família) } \\
\text { yes } \\
\text { no }\end{array}$ & $\begin{array}{l}36 \\
42 \\
\end{array}$ & $\begin{array}{l}93 \\
81\end{array}$ & $\begin{array}{c}96 \\
144 \\
\end{array}$ & $\begin{array}{l}57.3 \% \\
46.0 \%\end{array}$ & $\begin{array}{c}1.2 \\
1\end{array}$ & $1.0-1.5(\mathrm{NS})$ \\
\hline $\begin{array}{l}\text { Number of meals a day } \\
\text { up to three } \\
\text { more than three }\end{array}$ & $\begin{array}{l}25 \\
58 \\
\end{array}$ & $\begin{array}{c}59 \\
101\end{array}$ & $\begin{array}{c}54 \\
195 \\
\end{array}$ & $\begin{array}{l}59.7 \% \\
44.9 \% \\
\end{array}$ & $\begin{array}{c}1.3 \\
1 \\
\end{array}$ & $1.1-1.2$ \\
\hline $\begin{array}{l}\text { Number of pregnancies } \\
\text { one } \\
\text { more than one }\end{array}$ & $\begin{array}{l}37 \\
43\end{array}$ & $\begin{array}{c}79 \\
100\end{array}$ & $\begin{array}{c}80 \\
153\end{array}$ & $\begin{array}{l}59.1 \% \\
48.3 \% \\
\end{array}$ & $\begin{array}{c}1.2 \\
1\end{array}$ & $1.0-1.4(\mathrm{NS})$ \\
\hline $\begin{array}{l}\text { Number of prenatal visits } \\
\text { fewer than six } \\
\text { six or more }\end{array}$ & $\begin{array}{l}58 \\
34 \\
\end{array}$ & $\begin{array}{c}140 \\
40\end{array}$ & $\begin{array}{c}139 \\
81\end{array}$ & $\begin{array}{l}58.7 \% \\
47.7 \% \\
\end{array}$ & $\begin{array}{c}1.2 \\
1 \\
\end{array}$ & $1.0-1.5(\mathrm{NS})$ \\
\hline $\begin{array}{l}\text { Pregnancy planning } \\
\text { unplanned } \\
\text { planned }\end{array}$ & $\begin{array}{l}60 \\
30 \\
\end{array}$ & $\begin{array}{l}95 \\
64 \\
\end{array}$ & $\begin{array}{l}124 \\
116 \\
\end{array}$ & $\begin{array}{l}55.5 \% \\
44.7 \% \\
\end{array}$ & $\begin{array}{c}1.2 \\
1 \\
\end{array}$ & $1.0-1.5(\mathrm{NS})$ \\
\hline $\begin{array}{l}\text { Familiarity with folic acid } \\
\text { no } \\
\text { yes }\end{array}$ & $\begin{array}{l}13 \\
70\end{array}$ & $\begin{array}{c}21 \\
151\end{array}$ & $\begin{array}{c}18 \\
219\end{array}$ & $\begin{array}{l}65.3 \% \\
50.2 \%\end{array}$ & $\begin{array}{c}1.3 \\
1\end{array}$ & $1.0-1.6(\mathrm{NS})$ \\
\hline $\begin{array}{l}\text { Start of folic acid supplementation } \\
\text { after the first month } \\
\text { before pregnancy/ during first month }\end{array}$ & $\begin{array}{l}31 \\
34\end{array}$ & $\begin{array}{l}93 \\
44\end{array}$ & $\begin{array}{c}113 \\
94\end{array}$ & $\begin{array}{l}52.3 \% \\
45.3 \%\end{array}$ & $\begin{array}{c}1.1 \\
1\end{array}$ & $0.9-1.4(\mathrm{NS})$ \\
\hline
\end{tabular}

${ }^{\mathrm{a}}$ DFE $($ dietary folate equivalent $)=1 \mathrm{mcg}$ food folate $=0.6 \mathrm{mcg}$ folic acid from fortified foods

${ }^{\mathbf{b}} \mathrm{PR}=$ Prevalence Ratio $\quad(\mathrm{NS})=$ not significant 
Table 3: Foods consumed by the pregnant women which contributed most to their folate intake. Vale do Jequitinhonha, Brazil, 2013.

\begin{tabular}{|c|c|c|c|}
\hline \multirow[b]{2}{*}{ Foods Consumed } & \multicolumn{3}{|c|}{ Folate intake } \\
\hline & $\begin{array}{c}\mathrm{N}^{\circ} \text { of pregnant } \\
\text { women }(\%)\end{array}$ & $\begin{array}{c}\text { Mean } \\
(\mathrm{mcg} / \mathrm{DFE} / \mathrm{day})^{\mathrm{a}} \\
\pm \mathrm{SD}\end{array}$ & $\begin{array}{c}\text { Median } \\
(\mathrm{mcg} / \mathrm{DFE} / \mathrm{day})^{\mathrm{a}}\end{array}$ \\
\hline \multicolumn{4}{|l|}{ Fortified Foods } \\
\hline pasta & $431(87.6 \%)$ & $144.1 \pm 226.8$ & 64.6 \\
\hline white bread rolls and sliced & $373(75.8 \%)$ & $96.2 \pm 171.4$ & 40.7 \\
\hline savory pastries & $351(71.3 \%)$ & $37.1 \pm 66.1$ & 18.9 \\
\hline cake & $380(77.2 \%)$ & $30.5 \pm 55.4$ & 7.1 \\
\hline soup & $238(48.4 \%)$ & $56.5 \pm 102.8$ & 0.0 \\
\hline \multicolumn{4}{|l|}{ Unfortified Foods } \\
\hline beans & $467(94.9 \%)$ & $122.4 \pm 82.3$ & 151.6 \\
\hline oranges & $416(84.5 \%)$ & $42.4 \pm 58.6$ & 20.6 \\
\hline milk & $404(82.1 \%)$ & $12.4 \pm 12.9$ & 12.5 \\
\hline fruit juice & $330(67.1 \%)$ & $21.4 \pm 34.0$ & 9.6 \\
\hline tangerines & $327(66.5 \%)$ & $11.4 \pm 22.6$ & 2.6 \\
\hline
\end{tabular}

${ }^{\mathrm{a}} \mathrm{DFE}($ dietary folate equivalent $)=1 \mathrm{mcg}$ food folate $=0.6 \mathrm{mcg}$ folic acid from fortified foods 


\section{CONCLUSÕES GERAIS}

O presente trabalho proporcionou conhecer a prevalência de defeitos do tubo neural no Brasil e o padrão de consumo de folato em gestantes do Vale do Jequitinhonha, Minas Gerais, Brasil e, dessa forma, confirmar a efetividade da política de fortificação obrigatória das farinhas de trigo e milho com ácido fólico, realizada no Brasil em junho de 2004.

Este trabalho mostrou um declínio de 31,6\% na prevalência de DTN(s) entre os períodos antes e após fortificação obrigatória das farinhas de trigo e milho com ácido fólico. As reduções atingiram $34.1 \%$ nos casos de anencefalia e $31,0 \%$ nos casos de espinha bífida. Esses resultados promissores indicam que a fortificação de alimentos com ácido fólico é uma intervenção inquestionável na prevenção primária dos defeitos do tubo neural. A análise nacional de DTNs mostrou que a prevalência média foi de 0,79:1000 nascimentos para o período 2001-2004, e 0,54: 1000 nascimentos no período 2005-2010.

A avaliação do padrão de consumo de folato pelas gestantes do Vale do Jequitinhonha mostrou que a prevalência de consumo insuficiente de folato na dieta foi de $94,7 \%$, desconsiderando a inclusão de alimentos fortificados, $49,2 \%$, considerando a dieta com alimentos fortificados, e $17,1 \%$, considerando folato alimentar, alimentos enriquecidos, e suplementação com ácido fólico. Dessa forma, a política de fortificação foi responsável por uma redução de $45,5 \%$ na proporção de gestantes com consumo insuficiente de folato.

Os resultados deste estudo indicam que a fortificação de alimentos com ácido fólico nos níveis atuais reduz a inadequação do consumo na dieta, mas não é suficiente para suprir as necessidades e garantir os níveis seguros e adequados da oferta desse nutriente entre gestantes brasileiras.

Foi verificado, também, que há forte relação de fatores sócio-econômicos com a deficiência de consumo de folato. Baixa renda, baixa escolaridade e menor número de refeições diárias foram fatores de risco. O alimento que mais contribuiu na ingestão do folato na dieta das gestantes no Vale do Jequitinhonha foi o macarrão. 
Desse modo, fica evidenciado que a fortificação de alimentos com ácido fólico foi uma medida importante e eficaz na prevenção de DTNs no Brasil, sobretudo em regiões carentes como o Vale do Jequitinhonha.

\section{REFERÊNCIAS BIBLIOGRÁFICAS}

1. Botto LD, Moore CA, Khoury MJ, Erickson JD (1999) Neural tube defects Review articles. N Engl J Med 341:1509-1519.

2. Grillo E, Silva RJM (2003) Defeitos de tubo neural e hidrocefalia congênita: porque conhecer as suas prevalências? J Pediatr (Rio J) 79: 105-106.

3. Molloy AM (2005) The role of folic acid in the prevention of neural tube defects.Trends Food Sci Technol 16: 241-245.

4. Townsend CM, Beauchamp RD, Evers BM, Mattox KL (2009) Sabiston Tratado de cirurgia. Rio de Janeiro: Elsevier 2344 p.

5. Stevenson RE; Hall, JG; Goodman, RM. Human malformations and related anomalies. Oxford University Press, New York, 1993.

6. Pulikkunnel ST, Thomas SV (2005) Neural Tube Defects: Pathogenesis and Folate Metabolism. J Assoc Physicians India 53: 127-135.

7. Frey L, Hauser WA (2003) Epidemiology of neural tube defects. Epilepsia 44: 413.

8. Dolk H, Wals P, Gillerot Y; Lechat MF, Ayme S, et al. (1991) Heterogeneity of neural tube defects in Europe: the significance of site of defect and presence of other major anomalies in relation to geographic differences in prevalence. Teratology 44: 547-559.

9. Stevenson RE, Allen WP, Pai SG, Best R, Seaver LH, et al. (2000) Decline in Prevalence of Neural Tube Defects in a High-Risk Region of the United States. Pediatrics 106(4): 677-683.

10. Nascimento LFC (2008) Prevalência de defeitos de fechamento de tubo neural no Vale do Paraíba, São Paulo. Rev Paul Pediatr 26(4): 372-377. 
11. Aguiar MJ, Campos AS, Aguiar RA, Lana AM, Magalhães RL, et al. (2003) Defeitos de fechamento do tubo neural e fatores associados em recém-nascidos vivos e natimortos. J Pediatr (Rio J) 79 (n 2): 129-134.

12. Pacheco SS, Souza AI, Vidal AS, Guerra GV; Batista-Filho M, et al. (2006) Neural tube defects prevalence in newborn infants in the women care center of the InstitutoMaternolnfantil Prof. Fernando Figueira, IMIP: 2000-2004. Rev Bras Saude Mater Infant 6(Suppl 1): 35-42.

13. Nascimento LF, Pinto CO, Proença FP, Gotlieb SL (2006) Prevalência de anomaliascongênitas em São José dos Campos, Brasil em 2001. Rev Paul Pediatr 24: 47-51.

14. Castilla EE, Orioli IM, Lopez-Camelo JS, Dutra MG, Nazer-Herrera J (2003) Preliminary data on changes in neural tube defect prevalence rates after folic acid fortification in South America. Am J Med Genet A 123A(2): 123-128.

15. Lopez-Camelo JS, Castilla EE, Orioli IM (2010) Folic acid flour fortification: impact on the frequencies of 52 congenital anomaly types in three South American countries. Am J Med Genet A 152A: 2444-2458.

16. Creasy MR, Alberman ED (1976) Congenital malformations of the central nervous system in spontaneous abortions. J Med Genet 13: 9-16.

17. Machenry JCRM, Nevin NC, Merrett JD (1979) Comparison of central nervous system malformation in spontaneous abortions in Northern Ireland and south-east England. Br Med J (Clin Res Ed) 1:1395-1397.

18. Mezzomo CLS, Garcias GL, Sclowitz ML, Sclowitz IT, Brum CB, Fontana T, et al.(2007) Prevenção de defeitos do tubo neural: prevalência do uso da suplementação de ácido fólico e fatores associados em gestantes na cidade de Pelotas, Rio Grande do Sul, Brasil. Cad Saúde Pública 23:2716-26.

19. Vitolo MR. Nutrição: da gestação à adolescência. Rio de Janeiro: Reichmann \& Affonso Editores; 2003.

20.Scholl TO; Johnson WG (2000) Folic acid: influence on the outcome of pregnancy. Am J Clin Nutr, v. 71(5 Suppl), p. 1295S-303S.

21. Torrens C, Brawley L, Anthony, FW, Dance, CS, Dunn R, Jackson AA, Poston L, Hanson MA. Folate Supplementation During Pregnancy Improves Offspring Cardiovascular Dysfunction Induced by Protein Restriction. Hypertension. 2006; 47: 982-987. 
22. Kondo A, Kamihira O, Ozawa, H. (2009) Neural tube defects: Prevalence, etiology and prevention Int J Urol. 16:49-57.

23. Safi J, Joyeux L, Chalouhi GE (2012) Periconceptional folate deficiency and implications in neural tube defects. J Pregnancy, 2012:295083.

24. Blencowe H, Cousens S, Modell B, Lawn J (2010) Folic acid to reduce neonatal mortality from neural tube disorders. International Journal of Epidemiology, v. 39 (suppl 1), p. i110-i121.

25. Centers for Disease Control and Prevention. Recommendations for the use of folic acid to reduce the number of case of spina bifida and other neural defects. MMWR Recomm Rep 1992; 41(RR-14):1-7.

26. Institute of Medicine. Dietary reference intakes for thiamin, riboflavin, niacin, vitamin B6, folate, vitamin B12, pantothenic acid, biotin and coline. Washington DC: National Academy Press; 2000.

27. Brasil. Ministério da Saúde (2005). Agência Nacional de Vigilância Sanitária. RDC n. 269, de 22 setembro de 2005. Aprova o regulamento técnico sobre a Ingestão Diária Recomendada (IDR) de proteína, vitaminas e minerais. http:// elegis.anvisa.gov.br/leisref/public/showAct. php?id=18828\&word (acessado em 15 Junho de 2014).

28. Brasil. Ministério da Saúde (2002). Agência Nacional de Vigilância Sanitária ANVISA. Resolução - RDC no 344, de 13 de dezembro de 2002. Diário Oficial [da] República Federativa do Brasil, Brasília, DF. Available: http://www.anvisa.gov.br/legis/resol/2002/344_02rdc.htm. Accessed 15 June 2014.

29. Lima HT, Saunders C, Ramalho A. Ingestão dietética de folato em gestantes do município do Rio de Janeiro. Rev Bras Saúde Matern Infant 2002; 2: 303-11.

30. Trugo NMF Micronutrient regulation in pregnant and lactating women from Rio de Janeiro. Arch Latinoam Nutr 47 (2 Suppl 1): 30-34, 1997.

31. Fonseca VM, Sichieri R, Basílio L, Ribeiro LVC. Consumo de folato em gestantes de um hospital público do Rio de Janeiro. Rev Bras Epidemiol 2003; 6:319-27

32. Barros DC, Pereira RA, Gama SGN, Leal MC. O consumo alimentar de gestantes adolescentes no Município do Rio de Janeiro. Cad Saúde Pública. 2004; 20(1:S121-9):121-9. 
33. Azevedo DV, sampaio HAC. Consumo alimentar de gestantes adolescentes atendidas em serviço de assistência pré-natal. Rev Nutr. 2003; 16:273-80.

34. Brasil. Ministério da Saúde (2014) Razão entre nascidos vivos informados e estimados, Brasil 2000-2011. Available:

http://tabnet.datasus.gov.br/cgi/idb2012/a17b.htm. Accessed 15 June 2014.

35. Brasil. Ministério da Saúde (2014) Razão entre óbitos informados e estimados, Brasil 2000-2011. Available: http://tabnet.datasus.gov.br/cgi/idb2012/a1801b.htm. Accessed 15 June 2014.

36. Brasil. Ministério da Saúde (2010) Proporção de partos hospitalares, Brasil 2010. Available: $\quad$ http://tabnet.datasus.gov.br/cgi/deftohtm.exe?idb2012/f07.def. Accessed 15 June 2013.

37. Pereira MZ. Consumo alimentar em gestantes e os possíveis efeitos da fortificação obrigatória de farinhas com ácido fólico na ocorrência de defeitos de tubo neural no Distrito Federal.2007. 122 f. Dissertação (Mestrado em Nutrição Humana) - Universidade de Brasília, Brasília, 2007.

38. Pinheiro ABV, Lacerda EMA, Benzecry EH, Gomes MCS, Costa VM. Tabela para avaliação de consumo alimentar em medidas caseiras. São Paulo: Editora Atheneu; 2004.

39. Instituto Brasileiro de Geografia e Estatística (IBGE). Pesquisa de orçamentos Familiares. Tabela de Composição Nutricional dos Alimentos Consumidos no Brasil. Rio de Janeiro: IBGE; 2011.

40.Philippi ST. Tabela de Composição de Alimentos: suporte para decisão nutricional. 2. ed. Brasília: Editora Gráfica Coronário, 2002; 1:135 p.

41.Scholl TO, Hediger ML, Scholl JI, Khoo CS, Fisher RL. Dietary and serum folate: their influence on the outcome of pregnancy. Am J Clin Nutr 1996; 63:520-5.

42. Epi Info (TM) [computer program] Version 3.4. Database and statistics software for public health professionals. Centers for Disease Control and Prevention (CDC), 2007. 


\title{
8. ANEXOS
}

\section{ANEXO 8.1 - PARECER DO COMITÊ DE ÉTICA}

\author{
UNIVERSIDADE ESTADUAL DE MONTES CLAROS \\ COMITÊ DE ÉTICA
}

Unimontes

\section{PARECER CONSUBSTANCIADO}

Montes Claros, 09 de Novembro de 2011.

Processo N. ${ }^{\circ} 3094$

Título do Projeto: ESTUdo DA PREVALÊNCIA DE DEFEITOS DE TUBO NEURAL NO BRASIL E DO DO PADRÃO DE CONSUMO DE ÁCIDO FÓLICO E OCORRÊNCIA DE ANEMIA FERROPRIVA EM GESTANTES NO VALE DO JEQUITINHONHA, MINAS GERAIS, BRASIL.

\author{
Pesquisadores: Leonor Maria Pacheco Santos \\ Humberto Gabriel Rodrigues
}

\section{Relatora: Rosana Pinto Soares.}

\section{Histórico}

Justifica-se o presente estudo para explorar, de modo inédito, a ocorrência dos DTN no Brasil e da anemia ferropriva em gestantes do Vale do Jequitinhonha, Minas Gerais, Brasil, considerado pelos parâmetros da UNESCO uma das regiões mais pobres do mundo, de maneira a permitir o conhecimento da magnitude desses graves problemas de saúde pública e garantir aos mais excluídos uma melhor qualidade de vida. Em vista do impacto da deficiência de ferro e de ácido fólico em gestantes é importante que os profissionais de saúde tenham conhecimento da magnitude do problema, principalmente em regiões carentes. Justifica-se a localização do estudo no Vale do Jequitinhonha, Minas Gerias, Brasil, que é considerada pelos parâmetros da UNESCO (Organização das Nações Unidas para a Educação a Ciência e a Cultura) uma das regiões mais pobres do mundo. A pesquisa será realizada em 600 gestantes atendidas em maternidades de 15 municípios do Vale do Jequitinhonha, nas quais são realizados $78 \%$ dos partos desta região. Para a coleta de 
dados, será utilizado um questionário padronizado, que inclui um inquérito de consumo alimentar e a coleta capilar de sangue para diagnóstico de anemia ferropriva. A pesquisa da prevalência de DTN( Defeito Tubo Neural) na região será realizada por buscas nos sistemas SIM e SINASC mantidos pelo Ministério da Saúde e que registram a mortalidade e os nascidos vivos, respectivamente. Pretende-se ampliar o conhecimento da magnitude desses graves problemas de saúde pública na região e garantir aos mais excluídos uma melhor qualidade de vida.

\title{
Mérito
}

Trata-se de estudo descritivo baseado em dados primários e secundários. Na coleta de dados primários serão empregadas abordagens quantitativas e qualitativas. Os dados secundários são informações gerencias do Sistema de Mortalidade (SIM) e do Sistema de Informações sobre Nascidos Vivos (SINASC) do Ministério da Saúde que serão obtidas consultando páginas oficiais do DATASUS na internet e os sistemas internos do Ministério. Serão analisados os casos de DTN entre os nascidos vivos e entre os óbitos não fetais e fetais nos municípios do Vale do Jequitinhonha, Minas Gerais, Brasil.

\section{Parecer}

A presidência do Comitê de Ética em Pesquisa da Unimontes analisou o processo 3094, e entende que o mesmo está completo e dentro das normas do Comitê e das Resoluções do Conselho Nacional da Saúde/Ministério da Saúde. Sendo assim, somos pela Aprovação do projeto de pesquisa.

\author{
Ysom re \\ Prof."Dr "Maisa Tavares.de Souza Leite \\ Presidente do Comitê de Ética em Pesquisa da Unimontes
}




\section{ANEXO 8.2 - TERMO DE CONSENTIMENTO LIVRE E ESCLARECIDO}

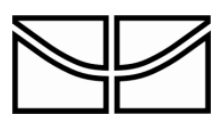

\section{UNIVERSIDADE DE BRASÍLIA FACULDADE DE CIÊNCIAS DA SAÚDE PROGRAMA DE PÓS-GRADUAÇÃO EM CIÊNCIAS DA SAÚDE}

\section{TERMO DE CONSENTIMENTO LIVRE E ESCLARECIDO}

NOME DA PESQUISA: ESTUDO DA PREVALÊNCIA DE DEFEITOS DE TUBO NEURAL NO BRASIL E DO PADRÃO DE CONSUMO DE ÁCIDO FÓLICO EM GESTANTES DO VALE DO JEQUITINHONHA, BRASIL.

PESQUISADOR RESPONSÁVEL: Humberto Gabriel Rodrigues INSTITUIÇÃO A QUE PERTENCE O PESQUISADOR RESPONSÁVEL: Universidade de Brasília (UnB), Brasília, Brasil.

TELEFONE PARA CONTATO: (38) 9119-1537

Você está sendo convidado(a) a participar, como voluntário(a), da pesquisa: Estudo da prevalência de defeitos de tubo neural no Brasil e do padrão de consumo de ácido fólico em gestantes do Vale do Jequitinhonha, Brasil. Caso concorde em participar, assine ao final do documento. Sua participação não é obrigatória, e, a qualquer momento, você poderá desistir de participar e retirar seu consentimento. Sua recusa não trará nenhum prejuízo em sua relação com o pesquisador(a) ou com a instituição. Você receberá uma cópia deste termo no qual consta o telefone e endereço do pesquisador(a) principal, podendo dirimir dúvidas do projeto e de sua participação. 
Esta pesquisa objetiva avaliar a prevalência de defeitos de fechamento do tubo neural no Brasil, bem como conhecer o padrão de consumo de ácido fólico de gestantes do Vale do Jequitinhonha, Minas Gerais, Brasil.

Para realização desta pesquisa, será aplicado questionário sócio-econômico e de conhecimentos gerais padronizado e um questionário padronizado, de frequência alimentar semiquantitativo.

Os participantes desta pesquisa não arcarão com nenhum gasto decorrente de sua participação nas entrevistas, não recebendo nenhuma cobrança com o que será realizado. E também não receberão qualquer espécie de reembolso ou gratificação devido à participação na pesquisa.

Os pesquisadores garantem sigilo que assegure a privacidade dos participantes quanto aos dados confidenciais envolvidos no questionário, informando que somente serão divulgados dados diretamente relacionados aos objetivos da pesquisa, mas com total anonimato.

$\mathrm{Eu}$,

$\mathrm{RG} \quad \mathrm{n}^{\mathrm{0}}$ declaro ter sido devidamente informado e concordo em participar, como voluntário, do projeto de pesquisa acima descrito.

Nome e assinatura do paciente ou seu responsável legal

Nome e assinatura do responsável por obter o consentimento 


\section{ANEXO 8.3 - QUESTIONÁRIO SÓCIO-ECONÔMICO}

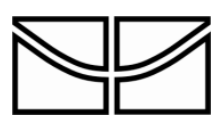

UNIVERSIDADE DE BRASÍLIA FACULDADE DE CIÊNCIAS DA SAÚDE PROGRAMA DE PÓS-GRADUAÇÃO EM CIÊNCIAS DA SAÚDE

\section{QUESTIONÁRIO SÓCIO-ECONÔMICO E DE CONHECIMENTOS GERAIS}

Título da Pesquisa: ESTUdo DA PREVALÊNCIA DE DEFEITOS DE TUBO NEURAL NO BRASIL E DO PADRÃO DE CONSUMO DE ÁCIDO FÓLICO EM GESTANTES DO VALE DO JEQUITINHONHA, BRASIL.

Orientador: Prof ${ }^{\mathrm{a}} \mathrm{Dr}^{\mathrm{a}}$ : Leonor Maria Pacheco Santos

Responsável: Humberto Gabriel Rodrigues

Data:

Entrevistador:

Obs.: Não se esqueça de:

1. Apresentar-se antes da entrevista.

2. Apresentar os objetivos da pesquisa.

3. Ler e explicar, quando necessário, o Termo de Consentimento Livre e Esclarecido.

4. Além de ler cada questão, explicá-la em caso de dúvida. 


\begin{tabular}{l} 
I- Dados Gerais \\
Q1: Município: \\
Q2: Unidade Básica de Saúde (UBS): \\
Q3: Entrevistador: \\
II- Identificação e sócio-econômico da Gestantes \\
Q4: Idade em anos: \\
Q5: Cor: $\square$ negra/parda $\square$ amarela $\square$ branca \\
Q6: Estado civil $\square$ Solteira $\square$ Casada $\square$ Viúva \\
$\square$ União estável com companheiro $\square$ divorciada/separada \\
Q7: Você mora com o companheiro \\
$\square$ sim $\square$ não (PULAR PARA A QUESTÃO 09) \\
\hline Q8: Até que série seu companheiro curou com aprovaça?
\end{tabular}

Q8: Até que série seu companheiro cursou com aprovação? (LER)

\begin{tabular}{l}
$\square$ Fundamental incompleto \\
\hline Fundamental completo \\
Médio incompleto \\
Médio completo \\
Superior incompleto \\
Superior completo \\
$\square$ IGN \\
Q9: Até que série você cursou com aprovação? (LER) \\
$\square$ Fundamental incompleto \\
$\square$ Fundamental completo \\
\hline Médio incompleto \\
\hline Médio completo \\
\hline Superior incompleto \\
Superior completo \\
IGN \\
Q10: Quantas pessoas moram na sua casa incluindo você?
\end{tabular}

\section{Q11: Renda da família}

$\square 1 / 4$ de salário mínimo ( $R \$ 169,50)$

$\square$ 1/2 de salário mínimo $(R \$ 339,00)$

$\square 1$ salário mínimo ( $R \$ 678,00)$

$\square 2$ salários mínimos ( $\mathrm{R} \$ 1356,00)$

$\square$ de 3 a 5 saláros mínimos ( $R \$ 2.034,00$ à $3.390,00)$

$\square$ de 6 a 10 saláros mínimos ( $R \$ 4.068,00$ à $6.780,00)$

$\square$ mais de 10 salários mínimos (mais que $6.780,00$ )

Q12: Você participa do programa Bolsa família?

$\square \operatorname{sim}$

$\square$ não (PULAR PARA A QUESTÃO 14)

Q13: Há quantos anos participa do programa Bolsa família ? menos de um ano ou
III- Agora gostaríamos de saber algumas informações sobre sua gravidez.

Q14: Quantas semanas você está de gravidez?

Q15: Esta gravidez foi planejada?

$\square \operatorname{Sim} \square$ Não

Q16: Você já ficou grávida antes?

$\square \operatorname{sim} \square$ Não ( PULAR PARA A QUESTÃO 18)

Q17: Quantas vezes incluindo esta gestação e abortos?

Q18: Você está esperando gêmeos? $\square$ Sim $\square$ Não IGN

Q19: Fez alguma consulta pré-natal?

$\square \operatorname{Sim} \square$ Não (PULAR PARA A QUESTÃO 21)

Q20: Até agora quantas consultas com o médico?

Q21: Você fumava antes da gestação? $\square$ Sim $\square$ Não

Q22: Você fuma agora? $\square$ Sim $\square$ Não

Q23: Você bebia bebida alcoólicas antes da gestação?

$$
\square \operatorname{Sim} \square \text { Não }
$$

Q24: Você bebe agora? $\square \operatorname{sim} \square$ Não

Q25: Você possui história familiar de defeitos como anencefalia ou espinha bífida? $\square \operatorname{sim} \square$ Não Q26: O médico que acompanha sua gravidez recomendou que você tomasse algum remédio?

$\square$ Sim $\square$ Não (PULAR PARA A QUESTÃO 28)

Q27: Qual o nome do remédio

Ácido fólico:

Quant vezes/dia

Multivitamínico de farmácia

Quant vezes/dia

\section{IV- Vamos Conversar Um Pouco Sobre Sua Alimentação}

Q28: Durante um dia quantas refeições (incluindo lanches) você faz?

Q29: Você já recebeu alguma orientação de como se alimentar?

$\square \operatorname{Sim} \square$ Não (PULAR PARA A QUESTÃO 32)

Q30: Essa orientação ocorreu... (ler as alternativas)

$\square$ antes de engravidar

$\square$ durante a gestação

$\square$ antes de engravidar e durante a gestação

$\square$ NS

Q31: Qual o objetivo dessa orientação alimentar (ler as alternativas)

$\square$ diminuir peso

$\square$ aumentar peso

$\square$ gestação saudável / não engordar muito

$\square$ outro/ especificar IGN 


\section{ANEXO 8.4 - QUESTIONÁRIO DE FREQUÊNCIA ALIMENTAR}

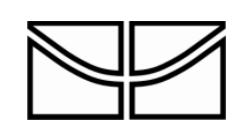

\section{UNIVERSIDADE DE BRASÍLIA FACULDADE DE CIÊNCIAS DA SAÚDE PROGRAMA DE PÓS-GRADUAÇÃO EM CIÊNCIAS DA SAÚDE}

\section{QUESTIONÁRIO DE FREQUÊNCIA ALIMENTAR}

Título da Pesquisa: ESTUdO DA PREVALÊNCIA DE DEFEITOS DE TUBO NEURAL NO BRASIL E DO PADRÃO DE CONSUMO DE ÁCIDO FÓLICO EM GESTANTES DO VALE DO JEQUITINHONHA, BRASIL.

Orientador: $\operatorname{Prof}^{\mathrm{a}} \mathrm{Dr}^{\mathrm{a}}$ : Leonor Maria Pacheco Santos

Responsável: Humberto Gabriel Rodrigues

Data:

Entrevistador:

Nome da Gestante:

Semanas Gestacionais:

Trimestre Gestacional:

Obs.: Não se esqueça de:

1. Ler sobre cada alimento,

2. Explicá-las em caso de dúvida, quanto ao tamanho de cada porção. 


\section{QUESTIONÁRIO DE FREQUÊNCIA ALIMENTAR}

\begin{tabular}{|c|c|c|c|c|c|}
\hline Grupo de alimentos & $\begin{array}{c}\text { (Durante a gestação) } \\
\text { Quantas vezes você } \\
\text { come }\end{array}$ & $\begin{array}{l}\text { Frequência } \\
\qquad(\text { Na } \\
\text { gestação) }\end{array}$ & Porção média & Sua porção & Cod. \\
\hline $\begin{array}{l}\text { Pão francês, pão de } \\
\text { forma. }\end{array}$ & N12345678910 & D S M G & 1 unidade $(50 \mathrm{~g})$ & P M G EG & 1 \\
\hline Bolos & N12345678910 & D S M G & 1 fatia G (100g) & P M G EG & 2 \\
\hline Pão integral & N12345678910 & D S M G & 2 fatias $(50 \mathrm{~g})$ & P M G EG & 3 \\
\hline $\begin{array}{l}\text { Biscoito Salgado (milho/ } \\
\text { cream cracker/ água e sal) }\end{array}$ & N 12345678910 & D S M G & 5 unidades $(33 g)$ & P M G EG & 4 \\
\hline Biscoito Doce & N12345678910 & D S M G & 10 unidades $(50 \mathrm{~g})$ & P M G EG & 5 \\
\hline Cereal Matinal & N12345678910 & D S M G & $\begin{array}{l}\text { (1 copo pequeno } \\
\text { cheio) }\end{array}$ & P M G EG & 6 \\
\hline Manteiga & N 12345678910 & D S M G & 1 ponta faca $(5 \mathrm{~g})$ & P M G EG & 7 \\
\hline Margarina comum & N12345678910 & D S M G & 1 ponta faca $(5 \mathrm{~g})$ & P M G EG & 8 \\
\hline Maionese & N12345678910 & D S M G & $1 \operatorname{col} \mathrm{S}(30 \mathrm{~g})$ & P M G EG & 9 \\
\hline Azeite & N 12345678910 & D S M G & $1 \mathrm{col} \mathrm{s}(8 \mathrm{~g})$ & P M G EG & 10 \\
\hline Bacon ou toicinho & N12345678910 & D S M G & $1 \mathrm{col} \mathrm{s}(16 \mathrm{~g})$ & P M G EG & 11 \\
\hline Requeijão & N12345678910 & D S M G & $\begin{array}{l}2 \text { pt faca } \mathrm{CH} \\
\quad(10 \mathrm{~g})\end{array}$ & P M G EG & 12 \\
\hline $\begin{array}{c}\text { Queijo branco } \\
\text { (fresco, ricota, cottage, } \\
\text { minas) }\end{array}$ & N 12345678910 & D S M G & $\begin{array}{l}2 \text { pdçs } M \\
(50 g)\end{array}$ & P M G EG & 13 \\
\hline $\begin{array}{c}\text { Queijos amarelos } \\
\text { (parmesão, mussarela, } \\
\text { provolone, prato) }\end{array}$ & N 12345678910 & D S M G & 2 fatia $M(30 g)$ & P M G EG & 14 \\
\hline $\begin{array}{c}\text { Mortadela, salame, } \\
\text { presunto, } \\
\text { peito de peru ou salsicha }\end{array}$ & N 12345678910 & D S M G & $\begin{array}{c}2 \text { fatia } M \\
(40 g)\end{array}$ & P M G EG & 15 \\
\hline Leite integral (comum) & N12345678910 & D S M G & $\begin{array}{c}1 \mathrm{cp} \mathrm{req} \mathrm{CH} \\
(250 \mathrm{~g})\end{array}$ & P M G EG & 16 \\
\hline Leite desnatado & N12345678910 & D S M G & $\begin{array}{c}1 \text { cp req } \mathrm{CH} \\
(250 \mathrm{~g})\end{array}$ & P M G EG & 17 \\
\hline Leite semidesnatado & N12345678910 & D S M G & $\begin{array}{c}1 \mathrm{cp} \mathrm{req} \mathrm{CH} \\
(250 \mathrm{~g})\end{array}$ & P M G EG & 18 \\
\hline $\begin{array}{l}\text { Mingau (aveia, milho, } \\
\text { fubá) }\end{array}$ & N12345678910 & D S M G & $\begin{array}{l}1 \text { prato fundo raso } \\
(200 \mathrm{~g})\end{array}$ & P M G EG & 19 \\
\hline $\begin{array}{c}\text { Iogurte integral } \\
\text { (Coalhada, iogurte natural } \\
\text { ou iogurte de frutas) }\end{array}$ & N 12345678910 & D S M G & $1 \mathrm{cp}$ Req r (200g) & P M G EG & 20 \\
\hline $\begin{array}{l}\text { Suco natural de outras } \\
\text { frutas com açúcar }\end{array}$ & N12345678910 & D S M G & $\begin{array}{c}1 \text { copo de Req CH } \\
(250 \mathrm{~g})\end{array}$ & P M G EG & 21 \\
\hline $\begin{array}{l}\text { Suco natural de outras } \\
\text { frutas sem açúcar }\end{array}$ & N12345678910 & D S M G & $\begin{array}{c}1 \text { copo de Req } \\
\mathrm{CH}(250 \mathrm{~g})\end{array}$ & P M G EG & 22 \\
\hline Suco artificial com açúcar & N12345678910 & D S M G & $\begin{array}{c}1 \text { copo de Req CH } \\
(250 \mathrm{~g})\end{array}$ & P M G EG & 23 \\
\hline Suco artificial sem açúcar & N12345678910 & D S M G & $\begin{array}{l}1 \text { copo de Req CH } \\
(250 \mathrm{~g})\end{array}$ & P M G EG & 24 \\
\hline
\end{tabular}




\begin{tabular}{|c|c|c|c|c|c|}
\hline Refrigerante & N12345678910 & D S M G & $\begin{array}{c}1 \text { copo de Req CH } \\
(250 \mathrm{~g})\end{array}$ & P M G EG & 25 \\
\hline Café com açúcar & N12345678910 & D S M G & $\begin{array}{l}1 \text { xícara de café } \\
(50 \mathrm{~g})\end{array}$ & P M G EG & 26 \\
\hline Café sem açúcar & N12345678910 & D S M G & $\begin{array}{c}1 \text { xícara de café } \\
(50 \mathrm{~g})\end{array}$ & P M G EG & 27 \\
\hline Mexerica & N12345678910 & D S M G & $\begin{array}{l}1 \text { unidade média } \\
\qquad(160 \mathrm{~g})\end{array}$ & P M G EG & 28 \\
\hline Laranja & N12345678910 & D S M G & $\begin{array}{l}1 \text { unidade média } \\
(160 \mathrm{~g})\end{array}$ & P M G EG & 29 \\
\hline Limão & N12345678910 & D S M G & $\begin{array}{l}1 \text { unidade média } \\
\qquad(160 \mathrm{~g})\end{array}$ & P M G EG & 30 \\
\hline Manga & N12345678910 & D S M G & $\begin{array}{l}1 \text { unidade média } \\
(180 \mathrm{~g})\end{array}$ & P M G EG & 31 \\
\hline Jaca & N 12345678910 & D S M G & $\begin{array}{l}1 \text { fatia média } \\
(200 \mathrm{~g})\end{array}$ & P M G EG & 32 \\
\hline Mamão papaia & N12345678910 & D S M G & $\begin{array}{l}1 \text { fatia média } \\
(170 \mathrm{~g})\end{array}$ & P M G EG & 33 \\
\hline Abacate & N 12345678910 & D S M G & $\begin{array}{l}1 \text { fatia média } \\
(147,5 \mathrm{~g})\end{array}$ & P M G EG & 34 \\
\hline Agrião cru & N 12345678910 & D S M G & 3 ramos $(18 \mathrm{~g})$ & P M G EG & 35 \\
\hline Agrião cozida & N 12345678910 & D S M G & 3 ramos $(18 \mathrm{~g})$ & P M G EG & 36 \\
\hline Rúcula crua & N 12345678910 & D S M G & 3 ramos $(18 \mathrm{~g})$ & P M G EG & 37 \\
\hline Rúcula cozida & N 12345678910 & D S M G & 3 ramos $(18 \mathrm{~g})$ & P M G EG & 38 \\
\hline Couve crua & N 12345678910 & D S M G & 1 pires $(30 \mathrm{~g})$ & P M G EG & 39 \\
\hline Couve cozida & N12345678910 & D S M G & 1 pires $(30 \mathrm{~g})$ & P M GEG & 40 \\
\hline Espinafre crua & N12345678910 & D S M G & 1 pires $(30 \mathrm{~g})$ & P M G EG & 41 \\
\hline Espinafre cozida & N 12345678910 & D S M G & 1 pires $(30 \mathrm{~g})$ & P M G EG & 42 \\
\hline Mostarda crua & N 12345678910 & D S M G & 1 folha (10g) & P M G EG & 43 \\
\hline Mostarda cozida & N 12345678910 & D S M G & 1 folha (10g) & P M G EG & 44 \\
\hline Alface crua & N 12345678910 & D S M G & $\begin{array}{c}1 \text { prato de } \\
\text { sobremesa }(36 \mathrm{~g})\end{array}$ & P M G EG & 45 \\
\hline Alface cozida & N 12345678910 & D S M G & $\begin{array}{c}1 \text { prato de } \\
\text { sobremesa }(36 \mathrm{~g})\end{array}$ & P M G EG & 46 \\
\hline $\begin{array}{l}\text { Tubérculos (batata, cará, } \\
\text { mandioca, inhame) }\end{array}$ & N12345678910 & D S M G & $\begin{array}{c}1 \text { escumadeira M } \\
\mathrm{R} \\
(95 \mathrm{~g})\end{array}$ & P M G EG & 47 \\
\hline Brócolis Cozido & N12345678910 & D S M G & 1 ramo $M(30 g)$ & P M G EG & 48 \\
\hline Quiabo cozido & N12345678910 & D S M G & $\begin{array}{l}1 \text { colher de sopa } \\
(26 \mathrm{~g})\end{array}$ & P M G EG & 49 \\
\hline
\end{tabular}




\begin{tabular}{|c|c|c|c|c|c|}
\hline Arroz Polido & N12345678910 & D S M G & $\begin{array}{c}2 \text { esc M CH } \\
(170 g)\end{array}$ & P M G EG & 50 \\
\hline Arroz integral & N12345678910 & D S M G & $\begin{array}{c}1 \mathrm{col} \mathrm{A} \mathrm{CH} \\
(134 \mathrm{~g})\end{array}$ & P M G EG & 51 \\
\hline Feijão & N12345678910 & D S M G & $\begin{array}{c}2 \text { concha M } \\
(156 \mathrm{~g})\end{array}$ & P M G EG & 52 \\
\hline Lentilha & N12345678910 & D S M G & $1 \operatorname{col~s} \mathrm{ch}(20 \mathrm{~g})$ & P M G EG & 53 \\
\hline Feijoada & N 12345678910 & D S M G & $\begin{array}{c}3 \mathrm{e}^{1 / 2} \operatorname{con} \mathrm{M} \\
(273 \mathrm{~g})\end{array}$ & P M G EG & 54 \\
\hline Lasanha & N 12345678910 & D S M G & $\begin{array}{c}1 \text { esc G r ou } 1 \\
\text { pedaço } P \\
(122,5)\end{array}$ & P M G EG & 55 \\
\hline Cuscuz de milho & N12345678910 & D S M G & $\begin{array}{c}1 \text { fatia pequena } \\
(85 \mathrm{~g})\end{array}$ & P M G EG & 56 \\
\hline Farofa de milho & N 12345678910 & D S M G & $\begin{array}{c}1 \text { colher de sopa } \\
\text { cheia }(15 \mathrm{~g})\end{array}$ & P M G EG & 57 \\
\hline Sopas (milho/fubá/macarrão) & N12345678910 & D S M G & $1 \mathrm{pt} \mathrm{R}(290 \mathrm{~g})$ & P M G EG & 58 \\
\hline Macarrão & N12345678910 & D S M G & $\begin{array}{l}2 \text { esc M CH } \\
(220 g)\end{array}$ & P M G EG & 59 \\
\hline Carne de boi & N12345678910 & D S M G & $\begin{array}{c}1 \text { filé } \mathrm{M} \text { ou } 3 \\
\text { pedaços } \mathrm{M}(100 \mathrm{~g})\end{array}$ & P M G EG & 60 \\
\hline Frango & N 12345678910 & D S M G & 1 filé M (180g) & P M G EG & 61 \\
\hline Carne de porco & N 12345678910 & D S M G & $\begin{array}{l}\text { 1,5 Filé } \mathrm{P}(150 \mathrm{~g}) \\
1 \text { gomo }(60 \mathrm{~g})\end{array}$ & P M G EG & 62 \\
\hline Peixe Fresco & N12345678910 & D S M G & 1 Filé M (100g) & P M G EG & 63 \\
\hline Atum & N 12345678910 & D S M G & 2 Col SP Ch (32g) & P M G EG & 64 \\
\hline Sardinha & N12345678910 & D S M G & 2 unidades $(82 \mathrm{~g})$ & P M G EG & 65 \\
\hline Ovo Cozido & N12345678910 & D S M G & $\begin{array}{c}1 \text { unidade } \\
(50 \mathrm{~g})\end{array}$ & P M G EG & 66 \\
\hline Ovo frito & N 12345678910 & D S M G & $\begin{array}{c}1 \text { unidade } \\
(50 \mathrm{~g})\end{array}$ & P M G EG & 67 \\
\hline $\begin{array}{c}\text { Fígado, rim, coração ou } \\
\text { moela. }\end{array}$ & N12345678910 & D S M G & $\begin{array}{l}1 \text { unidade M } \\
\quad(30 \mathrm{~g})\end{array}$ & P M G EG & 68 \\
\hline Sorvete (picolé) & N 12345678910 & D S M G & 1 bola G (100g) & P M G EG & 69 \\
\hline Tortas & N 12345678910 & D S M G & 1 fatia pequena (50g) & P M G EG & 70 \\
\hline Doces, balas & N12345678910 & D S M G & $\begin{array}{c}1 \text { unidade pequena } \\
(15 \mathrm{~g}) / 1 \text { unidade }(5 \mathrm{~g})\end{array}$ & P M G EG & 71 \\
\hline $\begin{array}{l}\text { Chocolate, achocolatado, } \\
\text { bombom. }\end{array}$ & N 12345678910 & D S M G & $\begin{array}{l}1 \text { bombom ou } 1 \\
\text { filete }(30 \mathrm{~g})\end{array}$ & P M G EG & 72 \\
\hline $\begin{array}{l}\text { Salgados (esfiha, rissole, } \\
\text { pastel, enroladinho) }\end{array}$ & N12345678910 & D S M G & $\begin{array}{l}1 \text { unidade } \mathrm{M} \\
\qquad(80 \mathrm{~g})\end{array}$ & P M G EG & 73 \\
\hline $\begin{array}{l}\text { Snacks (batata frita, } \\
\text { cheetos, amendoim) }\end{array}$ & N12345678910 & D S M G & $\begin{array}{c}1 \text { pacote }(96 \mathrm{~g}) \text { ou } \\
1 \text { saco } \mathrm{M} \\
\text { de pipoca }(20 \mathrm{~g})\end{array}$ & P M G EG & 74 \\
\hline $\begin{array}{c}\text { Sanduíches (cachorro } \\
\text { quente, sanduíche natural, } \\
\text { sanduíche tipo x-búrguer) }\end{array}$ & N 12345678910 & D S M G & 1 unidade $(125 \mathrm{~g})$ & P M G EG & 75 \\
\hline $\begin{array}{c}\text { Enlatados (milho, ervilha, } \\
\text { azeitona) }\end{array}$ & N12345678910 & D S M G & $\begin{array}{l}1 \text { colher de sopa } \\
(20 \mathrm{~g})\end{array}$ & P M G EG & 76 \\
\hline
\end{tabular}




\section{ANEXO 8.5 - CONVERSÃO DE MEDIDAS CASEIRAS DO QUESTIONÁRIO DE FREQUÊNCIA ALIMENTAR}

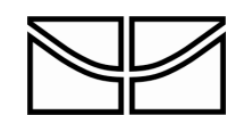

\section{UNIVERSIDADE DE BRASÍLIA FACULDADE DE CIÊNCIAS DA SAÚDE PROGRAMA DE PÓS-GRADUAÇÃO EM CIÊNCIAS DA SAÚDE}

\section{CONVERSÃO DE MEDIDAS CASEIRAS DO QUESTIONÁRIO DE FREQUÊNCIA ALIMENTAR}

Título da Pesquisa: ESTUdO DA PREVALÊNCIA DE DEFEITOS DE TUBO NEURAL NO BRASIL E DO PADRÃO DE CONSUMO DE ÁCIDO FÓLICO EM GESTANTES DO VALE DO JEQUITINHONHA, BRASIL.

\begin{tabular}{|l|l|}
\hline Alimento & \multicolumn{1}{|c|}{ Conversão } \\
\hline Abacaxi & $\begin{array}{l}1 \text { unidade média }=10 \text { fatias } \\
1 \text { copo de abacaxi picado }=2 \text { fatias } \\
\text { abacaxi em calda não considerar }\end{array}$ \\
\hline Abóbora & $\begin{array}{l}\text { pedaço Médio } 50 \mathrm{~g}=1,6 \text { colh sopa ch } \\
1 \text { concha }=4 \text { colh sopa ch }\end{array}$ \\
\hline Abobrinha & 1 rodela $=0,8$ colh sopa cheia \\
\hline Açúcar & 1 colh sopa $=2$ colh sobremesa \\
\hline Alface & 1 colh sopa $=2$ folhas \\
& 1 pé $(130 g)=52$ folhas \\
& $1 / 2$ prato $=16$ folhas \\
\hline Arroz & 1 colh servir $=2$ colh sop a \\
& 1 escumadeira $=4$ colh sopa \\
& 1 concha $=4$ colh sopa \\
\hline Atum & 1 colh servir $=2$ colh sop a \\
& 1 escumadeira $=4$ colh sopa \\
& 1 concha $=4$ colh sopa \\
\hline Bacon & 1 colh sopa $=1$ fatia \\
\hline Batata Cozida & 1 colh sopa $=0,5$ unidade \\
& 1 concha $=1,2$ unidades \\
\hline Batata Frita & 2 colh sopa $=1$ po rção \\
& 2 pedaços grandes $=1$ porção \\
& 1 unidade $=1$ porção \\
& 2 pegadores $=2$ porções \\
\hline Beterraba & 1 unidade $=5$ fatias \\
& 1 colh sopa $=0,6$ fatia \\
\hline &
\end{tabular}




\begin{tabular}{|c|c|}
\hline Biscoito Clube Social & $\begin{array}{l}1 \text { pacote (porção individual) }=3 \text { unidades } \\
\text { Cada unidade de biscoito salgado }=8 \mathrm{~g} \\
1 \text { pacote grande }(200 \mathrm{~g})=25 \text { unidades }\end{array}$ \\
\hline Bolacha Doce & $\begin{array}{l}1 \text { pacote }=36 \text { unidades (considerando que os } \\
\text { pacotes tem em média } 180 \mathrm{~g} \text { ) } \\
\text { pacote de } 500 \mathrm{~g}=100 \text { unidades }\end{array}$ \\
\hline Bolacha recheada & $\begin{array}{l}1 \text { pacote }=30 \text { unidades de biscoito doce } \\
\text { (considerando que os pacotes de } 160 \mathrm{~g} \text { em média) } \\
1 \text { bolacha }=2 \text { unidades de biscoito doce }\end{array}$ \\
\hline Bolacha salgada & 1 pacote $=25$ bolachas \\
\hline Bolo & $1 / 2$ bolo $=6$ fatias \\
\hline Bombom & 1 caixa $=10$ unidades \\
\hline Bucho & 1 concha $=2$ pedaços \\
\hline Café & $\begin{array}{l}\text { Considerar xícaras de qualquer tamanho como } \\
\text { uma unidade. Contar o açúcar separado. }\end{array}$ \\
\hline Camarão & $\begin{array}{l}1 \text { colh sopa }=1,6 \text { unidades } \\
100 \mathrm{~g}=4 \text { unidades } \\
1 \text { prato fundo de camarão = } 8 \text { unidades } \\
\text { Carne Moída } 1 / 2 \text { concha }=1 \text { porção }\end{array}$ \\
\hline Cenoura & $\begin{array}{l}1 \text { unidade }=4 \text { colh sopa cheias } \\
1 \text { concha }=4 \text { colh sopa ch }\end{array}$ \\
\hline Cerveja & $\begin{array}{l}1 \text { lata }=2 \text { copos } \\
1 \text { garrafa }=3,6 \text { copos }\end{array}$ \\
\hline Chicórea & $\begin{array}{l}1 \text { folha }=1 \text { colh sopa } \\
1 \text { pegador }=2 \text { colh sopa }\end{array}$ \\
\hline Chocolate & 1 barra $=6$ unidades \\
\hline Chuchu & $\begin{array}{l}1 / 2 \text { unidade }=2 \text { colh sopa } \\
1 \text { unidade }=5 \text { colh sopa } \\
1 \text { fatia }=0,7 \text { colh sopa }\end{array}$ \\
\hline Coração de galinha & $\begin{array}{l}7 \text { corações }=1 \text { pedaço } \\
2 \text { colheres de posa }=0,5 \text { pedaço }\end{array}$ \\
\hline Couve & $\begin{array}{l}1 \text { folha }=1 \text { colh sopa } \\
1 \text { maço }=12 \text { colh } \\
1 / 2 \text { panela }=10 \text { colh sopa } \\
1 \text { pegador }=2 \text { colh sopa }\end{array}$ \\
\hline Couve Flor & $1 / 3$ de unidade $=4,5$ ramos $/$ flor \\
\hline Doce de leite & 1 pote $=10$ colh sobremesa \\
\hline Ervilha & 1 concha $=4$ colh sopa \\
\hline Feijão ou lentilha & $\begin{array}{l}1 \text { concha }=4 \text { colh sopa }=2 \text { colh servir } \\
1 \text { xícara }=1 \text { concha }\end{array}$ \\
\hline Fígado & $300 \mathrm{~g}=6$ porções \\
\hline logurte & 1 litro $=7$ copos \\
\hline Leite & $\begin{array}{l}1 \text { copo de leite desnatado puro }=100 \mathrm{~g} \text { ( } 6 \text { copos de } \\
\text { leite fluido) }\end{array}$ \\
\hline Lentilha & 1 prato sopa $=8$ colh sopa \\
\hline Linguíça & $\begin{array}{l}1 \text { fatia }=0,5 \text { gomo } \\
1 \text { perna }=3 \text { gomos }\end{array}$ \\
\hline Macarrão & 1 escumadeira $=4$ colh sopa \\
\hline
\end{tabular}




\begin{tabular}{|c|c|}
\hline & $\begin{array}{l}1 \text { pacote massa nissin }=4 \text { porções macarrão } \\
1 \text { prato cheio }=3 \text { porções } \\
100 \mathrm{~g} \text { cozida }=1 \text { escumadeira } \\
100 \mathrm{~g} \text { crua }=2 \text { escumadeiras }\end{array}$ \\
\hline Maionese & $\begin{array}{l}1 \text { colh sopa = } 4 \text { colh chá } \\
1 \text { colh sobremesa = } 2 \text { colh chá } \\
1 \text { ponta de faca = } 1 \text { colh chá }\end{array}$ \\
\hline Mamão & $\begin{array}{l}1 / 2 \text { mamão comum = } 3 \text { fatias } \\
1 \text { pote de sobremesa cheio de mamão picado = } 1 \\
\text { fatia }\end{array}$ \\
\hline Manga & 1 fatia $=0,5$ unidade \\
\hline Melancia & $1 / 2$ melancia $=11$ fatias \\
\hline Melão & $\begin{array}{l}1 \text { unidade }=4 \text { fatias } \\
1 \text { potinho sobremesa }=0,5 \text { fatia }\end{array}$ \\
\hline Milho verde & 1 lata = 2 porções ( 8 colh sopa) \\
\hline Mocotó & 1 prato $=4$ porções de carne boi com osso \\
\hline Mondongo & $\begin{array}{l}\text { Cada 3,5 tias contar } 1 \text { porção. } \\
1 \text { concha = } 2 \text { porções }\end{array}$ \\
\hline Nescau & 1 colh sopa $=2$ colh sobremesa \\
\hline Pão caseiro & $\begin{array}{l}1 \text { unidade }=1 \text { fatia } \\
1 \text { unidade grande }=5 \text { fatias }\end{array}$ \\
\hline Peixe enlatado & 1 pedacinho $=0,3$ latas \\
\hline Pepino & $\begin{array}{l}1 / 2 \text { unidade }=16 \text { fatias } \\
1 \text { unidade pequena }=23 \text { fatias }\end{array}$ \\
\hline Pipoca & $\begin{array}{l}1 \text { saco }=1,5 \text { xícaras } \\
1 \text { bacia ou } 1 \text { panela }=6 \text { xícaras } \\
1 \text { pacote de microondas }=5 \text { xícaras } \\
70 \mathrm{~g} \text { milho cru }=4 \text { xícaras } \\
2 \text { xícara de cafezinho de milho cru }=6 \text { xícaras de } \\
\text { pipoca estourada }\end{array}$ \\
\hline Pizza & $\begin{array}{l}1 \text { pizza pequena }(\text { mini pizza })=2 \text { fatias } \\
1 \text { pizza média }=4 \text { fatias }\end{array}$ \\
\hline Polenta & $\begin{array}{l}2 \text { colh sopa }=1 \text { colh servir }=1 \text { pedaço } \\
1 \text { escumadeira }=1,5 \text { pedaços } \\
1 \text { concha }=2 \text { pedaços } \\
1 \text { caneca }=4 \text { pedaços } \\
1 \text { prato }=8 \text { pedaços }\end{array}$ \\
\hline Purê de batata & 1 colh sopa $=1$ unidade \\
\hline Queijo & $\begin{array}{l}1 \text { pedaço = } 1 \text { fatia } \\
2 \text { colh sopa rasas = } 1 \text { fatia }\end{array}$ \\
\hline Repolho & $\begin{array}{l}1 \text { pegador }=2 \text { colh sopa } \\
1 \text { pires }=3 \text { colh sopa } \\
1 \text { prato }=5 \text { colh sopa } \\
1 / 2 \text { repolho }=7 \text { colh sopa } \\
1 \text { colh servir }=2 \text { colh sopa } \\
3 \text { folhas }=7 \text { colh sopa }\end{array}$ \\
\hline Refrigerante & 2 litros $=12$ copos \\
\hline
\end{tabular}




\begin{tabular}{|l|l|}
\hline Salada de batata & 1 colh sopa $=1$ unidade \\
\hline Salgadinho & 1 punhado $=0,2$ pacote \\
\hline Salgado pequeno & 1 unidade $=0,25$ salgado \\
\hline Sardinha & 1 colh sopa $=0,1$ latas \\
\hline Sorvete & 1 litro $=12$ unidades \\
& 2 colh sopa cheias $=1$ unidade \\
& 2 bolas $=2$ unidades \\
\hline Suco & 1 jarra $=6$ copos \\
\hline Tomate & 1 undiade $=6$ fatias \\
\hline Uva & 2 grãos $=0,1$ cacho \\
\hline Vagem & 1 bacia $=10$ colh sopa \\
& 10 vagens $=3$ colh sopa \\
1 xícara $=3$ colh sopa \\
1 pegador $=2$ colh sopa \\
\hline
\end{tabular}




\section{ANEXO 8.6 - CARTA DE SUBMISSÃO}

\section{Bulletin \\ World Health Organization}

Dr. Santos,

MS ID\#: BLT/2014/150797

MS TITLE: Folic acid fortification is effective in the prevention of neural tube defects in Brazil

Thank you for the manuscript you have submitted to the Bulletin of the World Health Organization.

This manuscript is being considered. To follow the progress of your paper please go to: http://submit.bwho.org and log in to your Author Area.

If you have not registered with the system please click on 'Create a new account'. If you require any assistance with the registration process, please contact the editorial office at bulletin.submit.ask@who.int.

We thank you for your interest in the World Health Organization and the Bulletin.

Yours sincerely

Bulletin of the World Health Organization 


\section{ANEXO 8.7 - CARTA DE ACEITE}

\section{Publicación de manuscrito}

Estimado Profesor Rodrigues:

Es grato informarle que el manuscrito $\mathrm{N}^{\circ}$ 4107, "FOLIC ACID INTAKE BY PREGNANT WOMEN FROM VALE DO JEQUITINHONHA, BRAZIL AND THE CONTRIBUTION OF FORTIFIED FOODS" de los autores Rodrigues, H.C., Gubert, M.B. y Santos, I.M.P. ha sido aceptado para su publicación en Archivos Latinoamericanos de Nutrición, Volumen 65, Número 1, Enero de 2015.

Atentamente,

Josè Felix Chàvez Pèrez

Dr. Josè Felix Chàvez Pèrez

Editor General. ALAN 